\title{
EXCHANGE RATE MISALIGNMENTS AND INTERNATIONAL TRADE POLICY: IMPACTS ON TARIFFS ${ }^{1}$
}

\author{
Vera Thorstensen, Emerson Marçal, Lucas Ferraz ${ }^{2}$ \\ November, 2011
}

\begin{abstract}
The debate on "exchange wars and trade wars" is raising the attention of experts on international trade and economics. The main purpose of this paper is to analyze the impacts of exchange rate misalignments on one of the most traditional trade policy instruments - tariffs, as defined by the WTO - World Trade Organization. It is divided into three sections: the first one examines the effects of exchange rate variations on tariffs and its consequences for the multilateral trade system; the second explains the methodology used to determine exchange rate misalignments and also presents its results for Brazil, US and China; and the third summarizes the methodology applied to calculate the impacts of exchange rate misalignments on the level of tariff protection through an exercise of "misalignment tariffication".
\end{abstract}

\section{SECTION I}

\section{I - Introduction}

It is well-known that exchange rate variations affect international trade. One can ask, then, why this subject has been absent from international trade rules and WTO multilateral negotiations in Geneva.

Since the GATT, the IMF and the World Bank were created in the 1940s, a strict division of functions was established: the GATT would be responsible for international trade liberalization, the IMF would maintain the stability of exchange rates and balance of payments, and the World Bank would provide funds to Europe's reconstruction, after the Second World War. At that time, the multilateral trade system was created based on the dollar/gold standard, and even after it was changed to the flexible exchange system in the 1970s, the exchange rate issue remained controlled by the IMF, not being incorporated neither by the GATT nor the WTO.

\footnotetext{
${ }^{1}$ To be published at the Journal of World Trade, v. 46, i. 3, 2012

${ }^{2}$ Vera Thorstensen is a Professor at the São Paulo School of Economics (EESP) from FGV and Coordinator of the Center on Global Trade (CGTI); Emerson Marçal is a Professor at EESP-FGV and Coordinator of CEMAP and Lucas Ferraz is a Professor at EESP-FGV. Daniel Ramos, Carolina Muller and José Stucchi, from CGTI, and Priscila Fernandes Ribeiro, from CEMAP, were research assistants. This study is part of a Research Project on Global Trade Regulation, supported by IPEA-Instituto de Pesquisas Econômicas Aplicadas.
} 
While the world was under the US and EU (then, EEC) economic leadership, whenever exchange rate misalignments affected trade relations, the issue was discussed and negotiated by only a few parties, as demonstrated by the Plaza Agreement, in 1985. This agreement was reached by the US, the UK, Germany, France and Japan, and the main purpose was to devaluate the dollar. This kind of "agreement amongst a few" began to be challenged after some developing countries reached a more active position in the international trade arena, especially after China's accession to the WTO and its prominence as the world's biggest exporter.

It is important to clarify how the WTO has been dealing with the exchange rate issue throughout the years. Since 1947, Article XV of the GATT has established rules on exchange arrangements. Article XV.4 states that "Contracting parties shall not, by exchange action, frustrate the intent of the provisions of this Agreement, nor, by trade action, the intent of the provisions of the Articles of Agreement of the International Monetary Fund". The given meaning of the word "frustrate" is resumed in the Notes and Supplementary Provisions (Annex I) of Article XV, which explain that the intention is to indicate, for instance, that infringements of the letter of any article of the GATT by exchange rate actions shall not be regarded as a violation if, in practice, there is no appreciable misapplication of the purposes of the Article. So far, there are no examples, in the WTO, of the application of the Article XV.4, due to the fact that no member has ever questioned another member's exchange rate arrangements, as it demands the establishment of a panel and time for its conclusion. Besides the matter on how to define the concept of frustrated purposes, the main question is whether the WTO has to consult the IMF in such case.

The exchange rate concept is both mentioned in the Agreements on Anti-dumping and in the Agreement on Customs Valuation, but only with the purpose of indicating that the official exchange rates informed by governments are the ones to be considered in the investigations. Due to the escalation of exchange rate misalignments, which is responsible for opposing the US and China, as well as other Asian countries, several experts are examining the issue concerning the exchange rate impacts over international trade regulatory system, in order to define whether these misalignments could represent a violation of the WTO rules. Although many attempts of using trade remedies, such as anti-dumping and countervailing measures, to offset the exchange effects have been made, the results appear to be legally questionable, since trade remedies were not negotiated or agreed as mechanisms to inhibit the use of exchange rates as unfair trade.

In other words, the issue concerning how exchange rate variations affect trade has never been incorporated to the WTO rules. The only consensual rule was that exchange rate is an IMF matter. Therefore, raising this issue inside WTO rooms would represent an "infringement" of the concerted code of silence.

The problem is that the IMF is an international organization which does not have an enforcement mechanism such as the WTO's Dispute Settlement Body. It decides the relevant issues through an agreement amongst the most influential parties (those who own more voting power), in a political way. Unlike the WTO, which decides by consensus, the IMF does not have a negotiation nature.

Due to the intensification of the debate on the effects of exchange rates on trade since the 2008 financial crisis, the subject has been addressed to the G-20. However, in the 
present phase of multilateral crises, as expected, developed and emerging countries have failed to find a solution for the matter.

While experienced diplomats debate how to raise the issue and trade lawyers attempt to find a legal solution, economists have been proposing methodologies to calculate misalignments of exchange rates in relation to some equilibrium rates. There are several models for calculating equilibrium exchange rates: the purchasing power parity, the equilibrium of the current account, the equilibrium of assets and liabilities flows of a country, or the exchange rate based on the unit of labor costs. Banks also estimate the level of exchange misalignment with the purpose of anticipating future fluctuations. When reviewing all these studies, it becomes quite evident that the magnitude and the extension in time of these exchange rate misalignments for the main currencies are so significant that ignoring their effects on trade might undermine the objectives of the whole multilateral system.

It cannot be any longer accepted the argument that different exchange methodologies produce different results. The main target is not to search for an estimate with absolute degree of precision, but to discover limits where misalignments can cause trade distortions. What really matters is to find out a threshold from where trade policy instruments become ineffective and the WTO rules can be nullified.

In sum, maintaining the posture that exchange rates is a matter exclusively of the IMF's responsibility and that it does not affect the WTO is to ignore the obvious, that, indeed, exchange rates deeply affect trade. The WTO cannot continue to ignore the effects that exchange rates have on the trade system and its rules, at risk of losing touch with reality and transforming the organization into just a sophisticated juridical fiction!

Nevertheless, after the financial crisis of 2008, persistent misalignments of exchange rate raised the concern of some WTO members that the issue should not be left unattended. Brazil presented a submission to the Working Group on Trade, Debt and Finance (WGTDF) in April 2011, suggesting a work program consisting in an academic research on the relationship between exchange rates and international trade (WT/WGTDF/W/53). In September 20th, 2011, Brazil presented to the same working group a second proposal on the theme, suggesting the exam of available tools and trade remedies in the multilateral system that might allow countries to redress the effects of exchange rate misalignments (WT/WGTDF/W/56).

The WTO Secretariat presented its Note on a Review of Economic Literature in September $27^{\text {th }}, 2011$ (WT/WGTDF/W/57), as mandated by the Working Group. Although an extensive research, this work, encompassing the effects of exchange rates on economic flows, did not touch the issue of the impacts of exchange rate misalignment on WTO principles, rules and its instruments: tariffs, antidumping, subsidies, safeguards, rules of origin, GATT Articles I, II, III, XXIV, just to name some of the rules that are certainly being affected by exchange rates. In summary, the WTO Secretariat Notes speaks "IMF language", not "WTO language".

This paper objective is to study the impact of exchange rates misalignments on the most traditional WTO instrument - tariffs. It analyses the effects of exchange misalignments on tariffs, mainly on GATT Article II and GATT Article I (MFN). 


\section{II - Some estimates on exchange rate misalignments}

The purpose of this section is to present some methodologies and some estimates for misalignments to be used in some simulations on exchange rate tariffication. They will allow a more direct analysis of the effects of these misalignments on trade policy instruments.

There are different methodologies for the calculation of exchange rate misalignments on the literature. Some examples will be presented here.

\section{1 - Estimates of Cline and Williamson}

Cline, W. and Williamson, J. from the Peterson Institute for International Economics have been estimating equilibrium exchange rate misalignments related to the dollar based on the economic fundamentals (Fundamental Equilibrium Exchange Rate FEER), since 2008. A fundamental equilibrium exchange rate is defined as an exchange rate that is expected to be indefinitely sustainable on the basis of existing policies. It is considered to be the one expected to generate a current account surplus or deficit that matches the country's underlying capital flow over the cycle, assuming that the country seeks internal balance (Cline, Wiliamson, PB11-5, 2011).

The misaligned rates vary according to the model's hypothesis and to the relevant data which are incorporated.

\section{2 - Estimates of Credit Suisse Bank}

Credit Suisse has also estimated exchange rate misalignments for some developing countries. The Bank calculated the value of the Real Effective Exchange Rates (REER), as a function of terms of trade, productivity and interest rates, for the period 1995 to 2010. Sophisticated econometric methods based on the panel data are used.

Graphic 1: Exchange rate misalignments regarding the equilibrium exchange rate elaborated by Credit Suisse:

Deviation of December 2010 and 12 January 2011 REERs from the fair value estimates of REERs

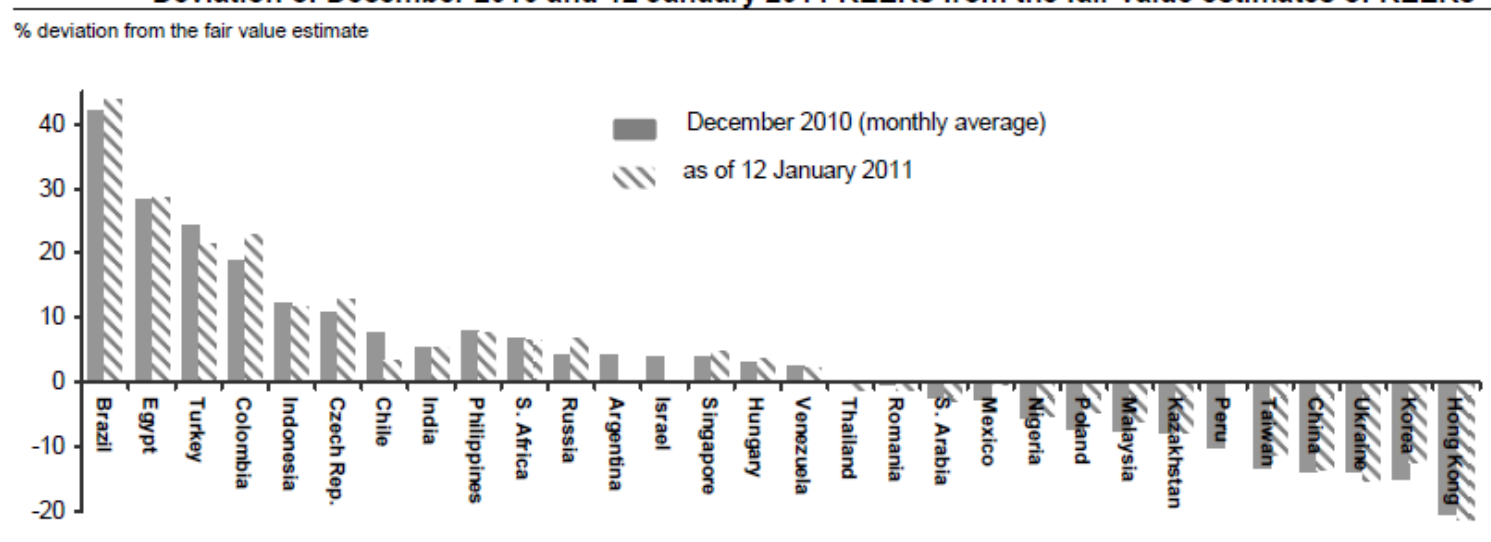

Note: For Argentina, Israel and Peru, the latest available data are for November 2010.

Source: Credit Suisse 


\section{3 - Estimates for China}

China is one of the most studied cases, due to its increasing importance on international trade scenario.

A few estimates of China's exchange rate misalignments are presented in the literature:

- $12 \%$ - H. Reisen, OEDC, 12/2009.

- $25 \%$ - D. Rodrick, Harvard University, 12/2009.

- $30 \%$ - A. Subramanian, Peterson Institute, 4/2010.

- $40 \%(1 / 2010)$ e $24 \%$ (6/2010) - W.Cline and J. Williamson, Peterson Institute.

- $50 \%$ - N. Fergunson, M. Schularick, Harvard University, 10/2009.

The IMF also presented some estimates on China's misalignments on the last two Reports on Article IV. Considering the relevance of the effects of China's exchange rate misalignments on the international economy, the conclusions described on the last two Staff Report for Article IV Consultations, of 2010 and 2011, are revealing: 2011's Reports states that: "Staff continues to believe that the renminbi remains substantially below the level consistent with medium-term fundamentals. At this point, there is little reason to change the assessment made during the 2010 Article IV Consultation".

Only on its footnote this Report shows the estimates of IMF's Consultative Group: "The current estimates of the Consultative Group on Exchange Rates indicate that the renmimbi is undervaluated by 3\% (ERER approach), 17\% (ES approach) and 23\% (MB approach)" (China Report on Article IV Consultation, page 18).

\section{4 - Estimates of CEMAP}

CEMAP - The Center on Applied Macroeconomics of the São Paulo School of Economics from of Getúlio Vargas Foundation has been calculating Brazil's exchange rate misalignments since 2009. CEMAP estimates real equilibrium exchange rate that implies on the stability of net foreign asset position of a country, by using an econometric model of co-integration to Brazil (1980 to 2010), to the US (1970 to 2010) and China (1980 to 2010). The estimates for other G20's countries are in progress. The description of the methodology is presented on Section II of this paper.

The main results can be seen in the following graphics:

\section{Graphic 2: Brazil - exchange rate misalignments}

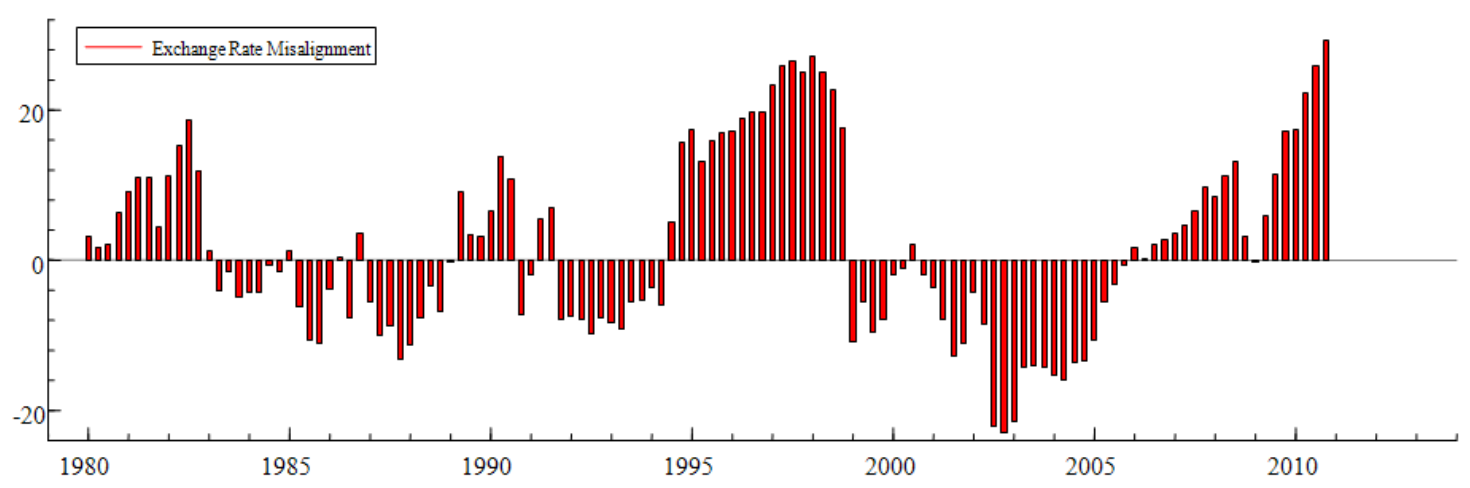


Graphic 3: United States - exchange rate misalignments

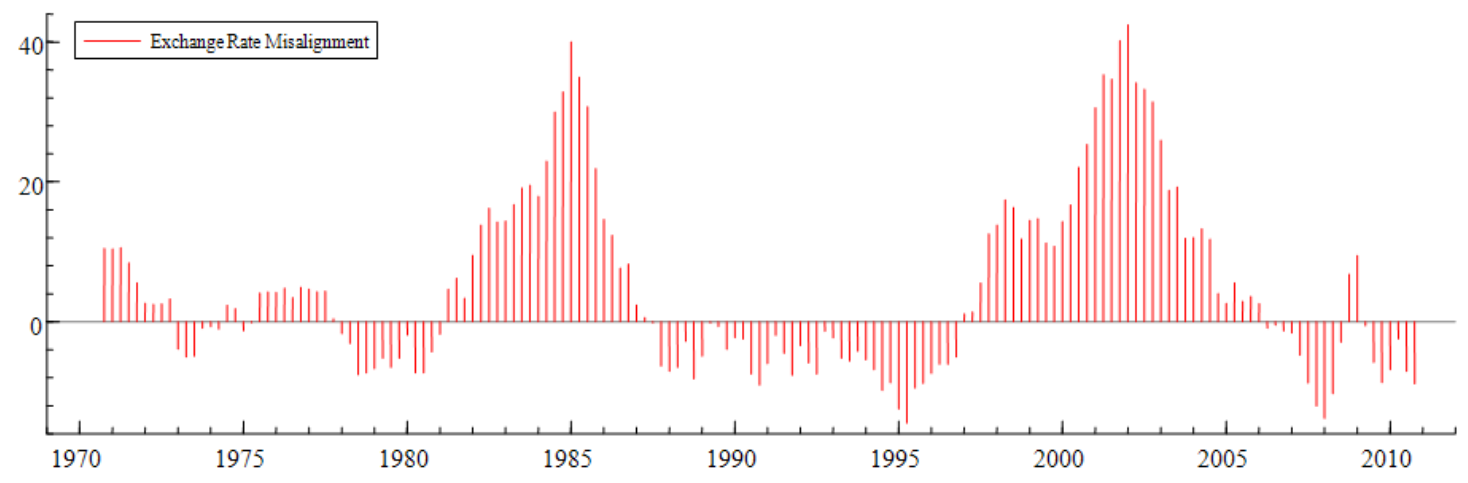

Graphic 4: China - exchange rate misalignments

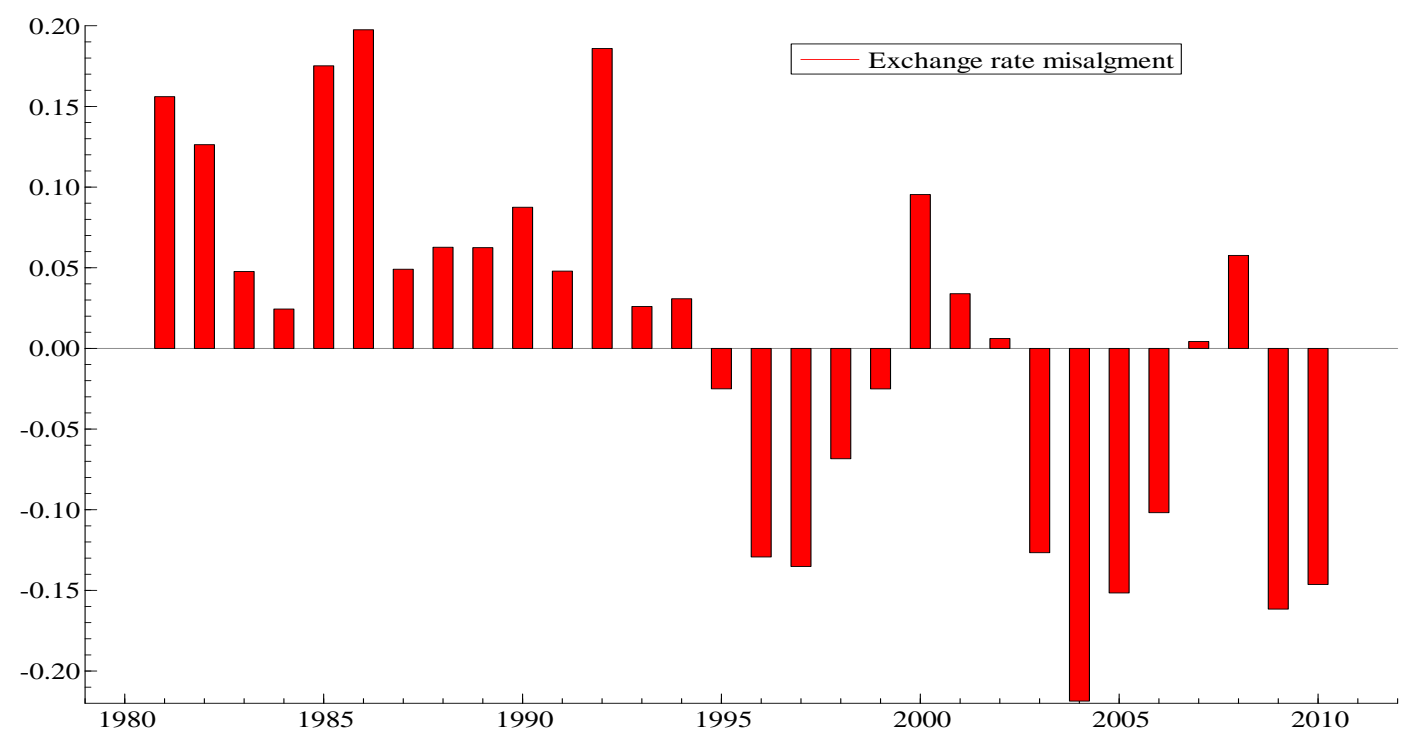

Considering the year 2010, the exchange rate misalignments for Brazil, US and China are the following:

- Brazil $+29 \%$ (overvaluation)

- US $-10 \%$ (undervaluation)

- China $-17 \%$ (undervaluation)

\section{Some conclusions}

There is a wide literature presenting different methodologies and sophisticated econometric models to estimate countries exchange rate misalignments. The bibliography presented in Section II of this paper indicates some of the most recognized authors in this area.

According to several sources, the most elaborated model concerning misalignments is the one used by IMF's Consultative Group on Exchange Rate. The problem is that those 
estimates are not published in details in the Staff Report for Article IV Consultations that periodically examine members' exchange rates and balance of payments progress.

It is relevant to emphasize that transparency rules, strongly supported by some and little respected by others, are not accepted by all IMF members. The increasing importance of the exchange rate issue demonstrates the urgency that the IMF publishes the estimates of its member's exchange rate misalignments, as well as the applied methodology, allowing WTO members to analyze their impacts on their trade instruments.

\section{III - The effects of exchange rate misalignments on trade policy instruments: the case of bound and applied tariffs}

The next question to be raised is how such misalignments affect the international trade policy instruments negotiated by the GATT/WTO over the last 60 years.

It is possible to develop a methodology to analyze the effect of exchange rate misalignments on either bound tariffs, negotiated by a country as a compromised ceiling for the tariff of each product, or on applied tariffs, used by such member as a protection level determined by its Trade Policy.

Tariffs are a GATT's historical instrument for trade protection and one of the main negotiating subjects included in multilateral rounds. Its purpose is to allow an objective and transparent protection for agricultural and non-agricultural goods, and to be reduced over time, as a result of trade liberalization. The difference between bound and applied tariffs represents an important space available for industrial policy purposes, the so called policy space, strongly defended by developing countries and highly critized by developed countries.

A quite realistic picture of each WTO member tariff protection's framework can be given by a graphic showing tariff averages for each chapter of the Harmonized Commodity Description and Coding System - HS (97 chapters), which includes: foodstuff, mineral, textiles, machines, electronics, vehicles and aircrafts, amongst others.

The concepts of tariff and tariffication are the core of the GATT/WTO logic. Endless hours have been spent in all negotiation rounds to estimate the ad valorem equivalent rates of several duties expressed on a monetary basis, such as specific rate duties and variable levies. Even in the cases of anti-dumping, countervailing measures and safeguards, the duties are equivalent to tariffs. According to this logic, exchange rate misalignments can also be tariffied through the calculation of a tariff equivalent. Just like tariffs, the effect of the exchange rate can be transferred to imported and exported goods' prices.

The exchange rate misalignment tariffication methodology is developed in Section III of this paper.

\section{Impacts of exchange rate misalignments on tariffs levels}

Some simulations can be developed based on the estimates of exchange rate misalignments and its tariff equivalents, obtained through the tariffication of exchange rates. 
It is important to stress that this paper is not searching for the precise value of the exchange rate misalignments, but the threshold beyond which trade policy instruments become ineffective. A member, with these numbers at hand, could figure out how to neutralize the effects of exchange rate on trade and to regain the effectiveness of its tariffs and other GATT/WTO rules negotiated all throughout the rounds.

This paper explores a few hypotheses, using approximated values for misalignments calculated by CEMAP/FGV and present in the literature. For Brazil, US and China, the assumed values are the following:

- Brazil $+30 \%$

- US $-10 \%$

- China $-20 \%$

The values of tariffs used for Brazil, US and China were obtained in the WTO database (Tariff Analysis Online) and dated from 2008 to 2010. A comparison is presented using: - bound tariffs - simple average at HS 2 digits

- applied tariffs - simple average at HS 2 digits

In this simulation, the effects of exchange rates were calculated at HS 2 digits simple averages to illustrate the direct impact on tariff rules. Simulations using 4 and 6 digits and weighted averages were also analyzed, but they are not presented in this paper because the results show us the same conclusions.

The simulations at HS 2 digits present the following:

\section{1 - Effects of exchange rates on tariff averages for Brazil, US and China}

The effects of tariffied exchange rates can be visualized on the variation of both bound and applied average tariffs for these four countries. In this paper Brazil, US and China's bound and applied tariffs were examined using the results of the misalignments of their exchange rates.

The results of the simulations show that the effects of exchange rate misalignments on tariff averages are considerable.

- Brazil - for a valuation of its exchange rate at $+30 \%$, its bound and applied average tariffs become negative, representing an incentive to imports.

- US - for a devaluation of - $10 \%$, their bound and applied average tariffs increase above the current level, representing an extra-tariff to imports.

- China - for devaluation of $-20 \%$, its bound and applied average tariffs significantly increase, representing an extra-tariff to imports. 


\section{Table 1:}

\begin{tabular}{|l|r|r|r|}
\hline \multicolumn{4}{|c|}{$\begin{array}{c}\text { Impacts of Exchange Rates on Tariffs for Brazil, US and China } \\
\text { Misalignments: Brazil } 30 \% \text { overvaluation; China } 20 \% \text { devaluation; the US }\end{array} 10 \%$ devaluation } \\
\hline Tariffs & Brazil & China & US \\
\hline Simple average bound rates (2009) & $31,4 \%$ & $10 \%$ & $3,5 \%$ \\
Adjusted simple average bound rates & $-8,0 \%$ & $32 \%$ & $13,9 \%$ \\
\hline Simple average MFN applied rates (2009) & $13,6 \%$ & $9,6 \%$ & $3,5 \%$ \\
Adjusted simple average MFN applied rates & $-20,5 \%$ & $31,5 \%$ & $13,9 \%$ \\
\hline Trade weighted average applied rates (2008) & $8,8 \%$ & $4,3 \%$ & $2,0 \%$ \\
Adjusted trade weighted average applied rates & $-23,8 \%$ & $25,2 \%$ & $12,2 \%$ \\
\hline
\end{tabular}

\section{2 - Effects of exchange rates on Brazil's tariffs}

i) For a $30 \%$ overvaluation of Brazil's exchange rate, the results are the following:

- Brazil's average bound tariffs, which currently vary from $+12 \%$ to $+50 \%$, with an overvaluation of $+30 \%$ will vary from $-22 \%$ to $+4 \%$, most of them presenting negative values.

- Brazil's average applied tariffs, which currently vary from $0 \%$ to $+35 \%$, due to its exchange rate overvaluation, will vary from $-30 \%$ to $-5 \%$.

\section{Graphic 5:}

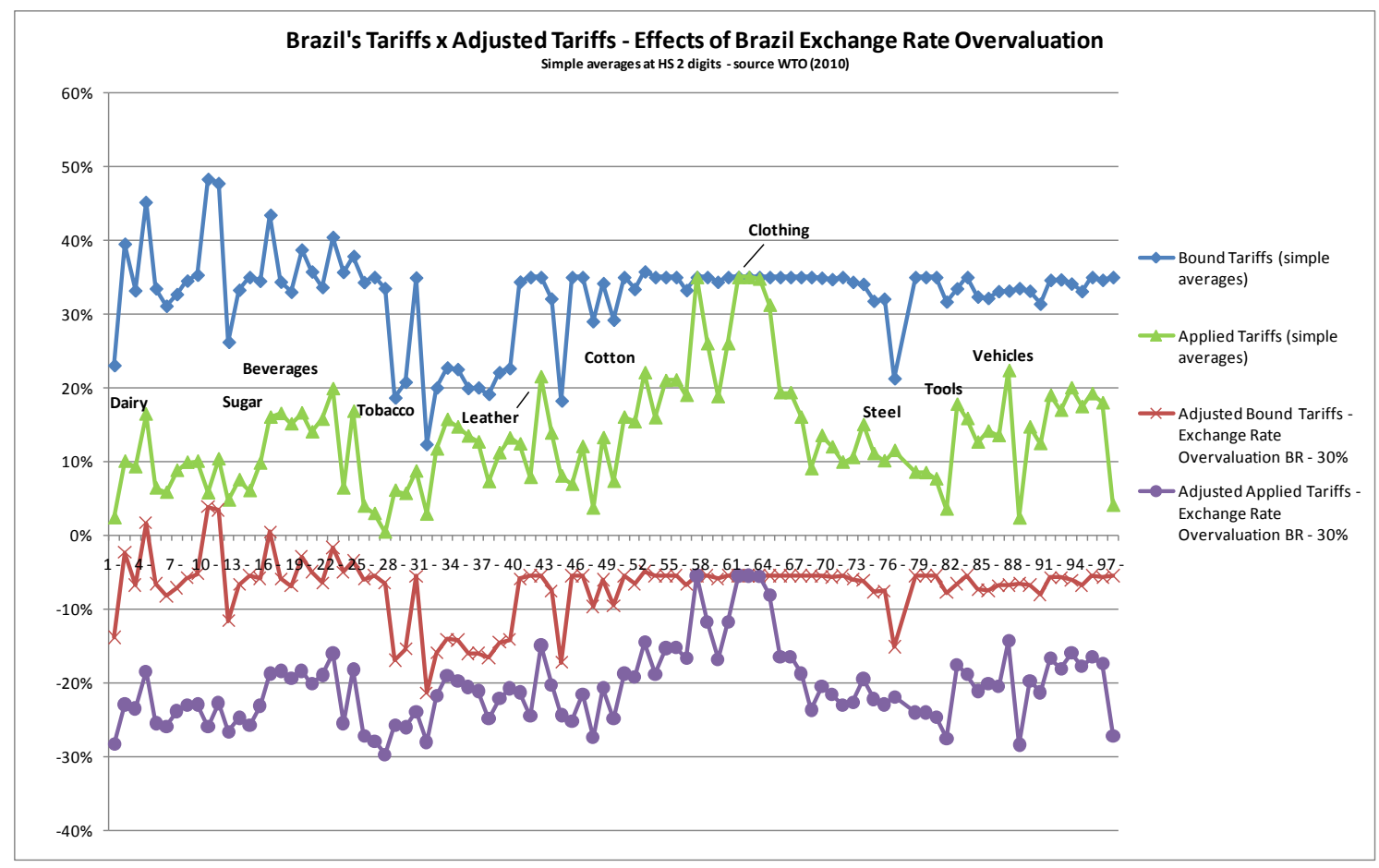

In summary, exchange rate overvaluation at a $+30 \%$ level, represents not only a nullification of Brazil's bound tariffs but also an incentive to imports, since the applied tariffs are reduced to negative levels. 
In this scenario, to ask for any significant cut on bound tariffs, as in the Doha Round, would mean imposing larger distortions to the already negotiated tariff level. The same observation can be made in the context of negotiations in preferential trade agreements.

ii) Considering a devaluation of $10 \%$ for the US' exchange rate, the effects in Brazil would be the following:

- Brazil's average bound tariffs, currently varying from $+12 \%$ to $+50 \%$, when adjusted to the US devaluation will vary from $+2 \%$ to $+35 \%$.

- Brazil's average applied tariffs, currently varying from $0 \%$ to $+35 \%$, will vary from $-10 \%$ to $+22 \%$.

iii) Considering devaluation of $20 \%$ for the China's exchange rate, the effects on Brazil would be the following:

- Brazil's average bound tariffs, currently varying from $+12 \%$ to $+50 \%$, when adjusted to China devaluation will vary between $-10 \%$ and $+19 \%$.

- Brazil's average applied tariffs, currently varying from $0 \%$ to $+35 \%$, will vary from $-20 \%$ to $+8 \%$.

iv) Combining the $30 \%$ overvaluation of Brazil's exchange rate with the $20 \%$ devaluation of China's exchange rate, the effects in Brazil would be the following:

- Brazil's average bound tariffs, currently varying from $+12 \%$ to $+50 \%$, when adjusted to both devaluations will vary from $-44 \%$ to $-25 \%$.

- Brazil's average applied tariffs, currently varying from $0 \%$ to $+35 \%$, will vary from $-50 \%$ to $-32 \%$. 


\section{Graphic 6:}

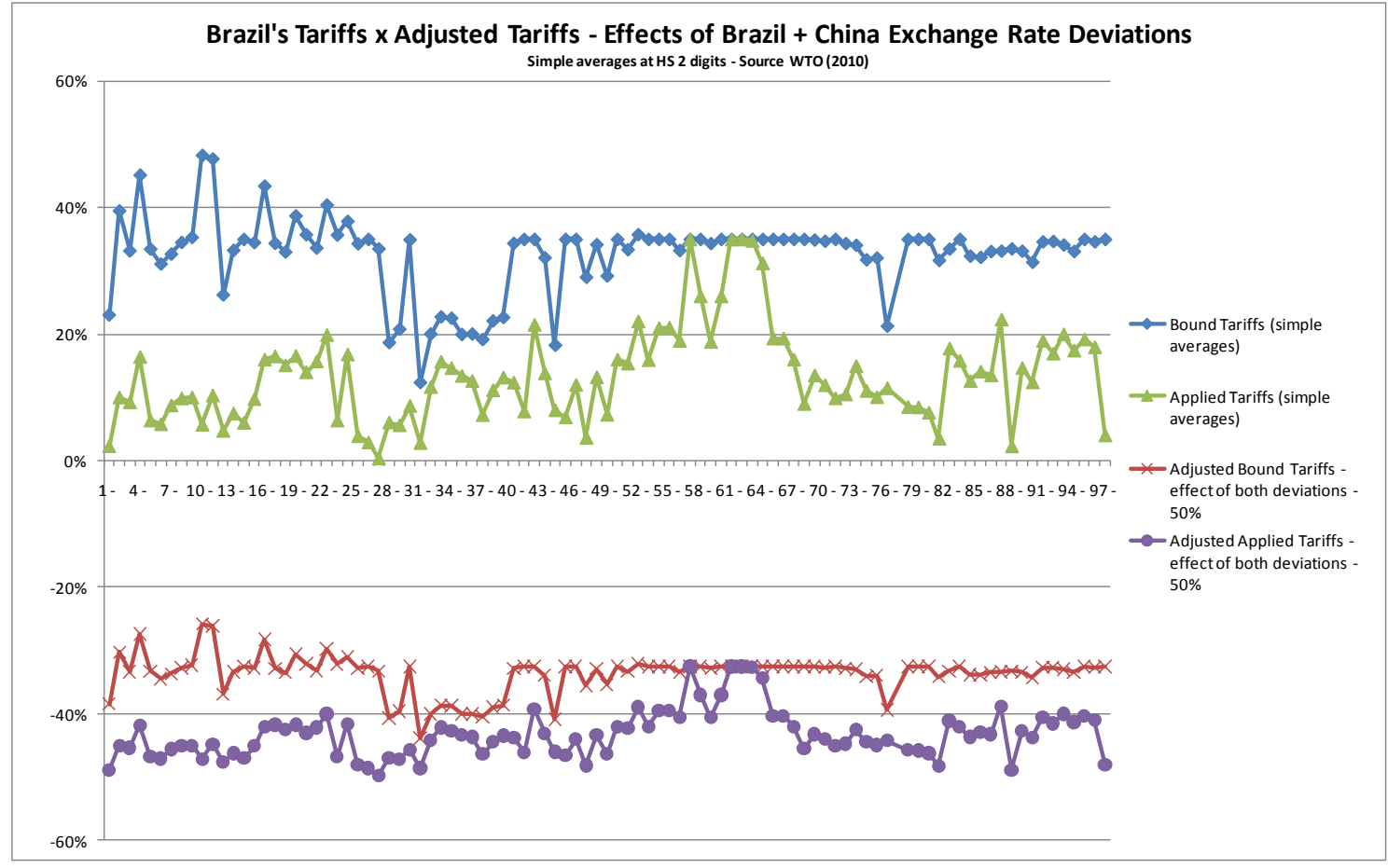

In summary, the US and China's exchange rate devaluations, which represents a subsidy to their exports, not only nullify Brazil's negotiated bound tariffs, but also transform Brazil's applied tariffs into a stimulus to US and China's imports.

The overvaluation of Brazil's currency virtually nullifies the tariff instrument, representing a stimulus to imports in general. When faced with devaluated currencies, the WTO's negotiated tariff levels can be further affected, which shows that Brazil is offering a much larger market access that the one negotiated at WTO.

\section{3 - Effects of exchange rates on the US' tariffs}

The US' average bound and applied tariffs, in the double-digit HS graphic, present close values, and vary from $0 \%$ to $+13 \%$ (except HS Chapter $24-$ tobacco, which average is around $140 \%$ ).

i) Considering a devaluation of $10 \%$ in the US' exchange rate:

- The effect of a $10 \%$ exchange rate devaluation on tariffs currently varying from $0 \%$ to $+13 \%$, will result in tariffs varying from $+10 \%$ to $+25 \%$. Therefore, tariffs will become well above the bound values negotiated by the US at the WTO. 


\section{Graphic 7:}

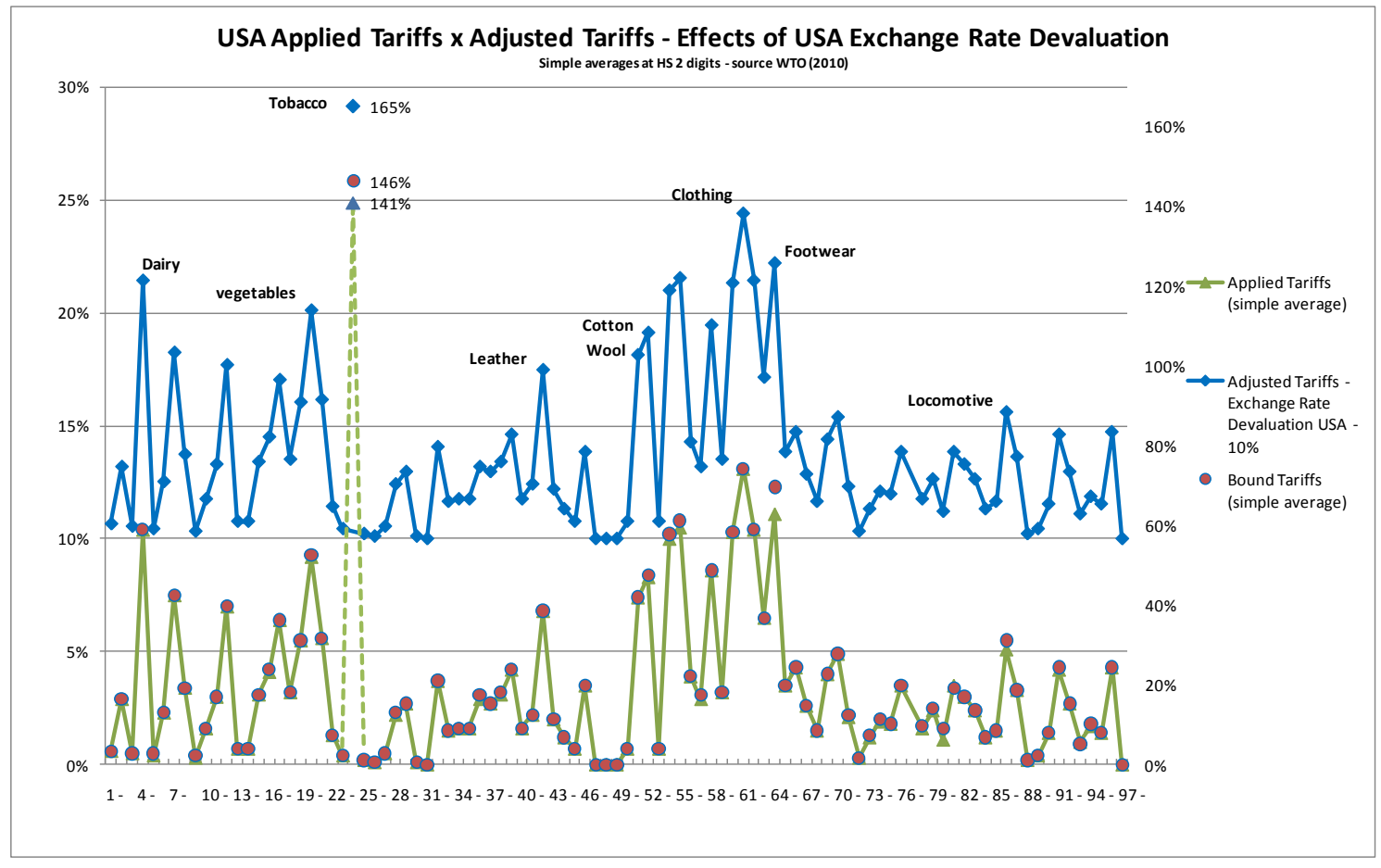

ii) Considering a devaluation of $20 \%$ in the China's exchange rate:

- The effect of China's $20 \%$ exchange rate devaluation, will result in US tariffs currently varying from $0 \%$ to $+13 \%$, in tariffs varying from $-20 \%$ to $-10 \%$.

iii) When the effects of both deviations are calculated simultaneously, the effects in the US will be the following:

- Considering the effect of China's $20 \%$ exchange rate devaluation and US's $10 \%$ exchange rate devaluation, those tariffs currently varying from $0 \%$ to $+13 \%$, will vary from $-10 \%$ to $+2 \%$. 


\section{Graphic 8:}

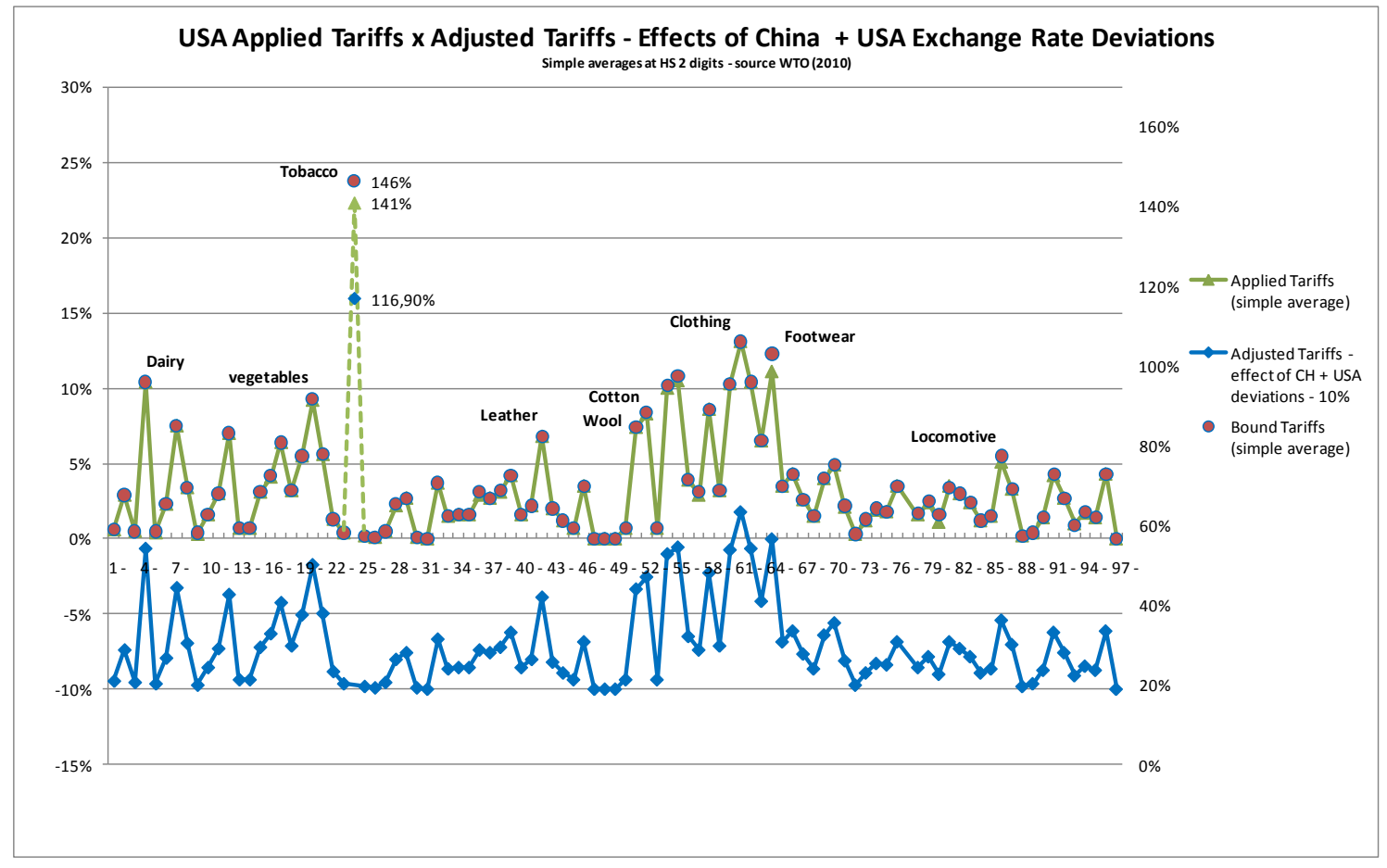

In summary, the devaluation of the exchange rate not only represents a stimulus to devaluated currency countries' exports, but also creates an extra-tariff to other countries' imports. Due to the fact that bound and applied rates are almost the same for some countries, the adjusted tariffs became values well above the WTO's bound tariffs.

One could question whether those countries are violating the WTO's rules, especially GATT Article II, which establishes that the contracting parties shall not apply tariffs in excess to the bound tariffs.

In the other hand, the offset effect of two different exchange rate devaluations - the importing country's devaluation having the effect of increasing its tariffs while the exporting country's devaluation lowering them - demonstrates the potential "race to the bottom" consequence of competitive exchange rate devaluations.

\section{4 - Effects of exchange rates on China's tariffs}

China's average bound and applied tariffs, in the double-digit HS, also present close values, and vary from $0 \%$ to $+33 \%$.

i) Considering a devaluation of $20 \%$ in China's exchange rate:

- With an exchange rate adjustment of $20 \%$ devaluation, those tariffs currently varying from $0 \%$ to $+33 \%$, will vary from $+20 \%$ to $+57 \%$. Therefore, these tariffs are also well above the bound values negotiated by China at the WTO. 


\section{Graphic 9:}

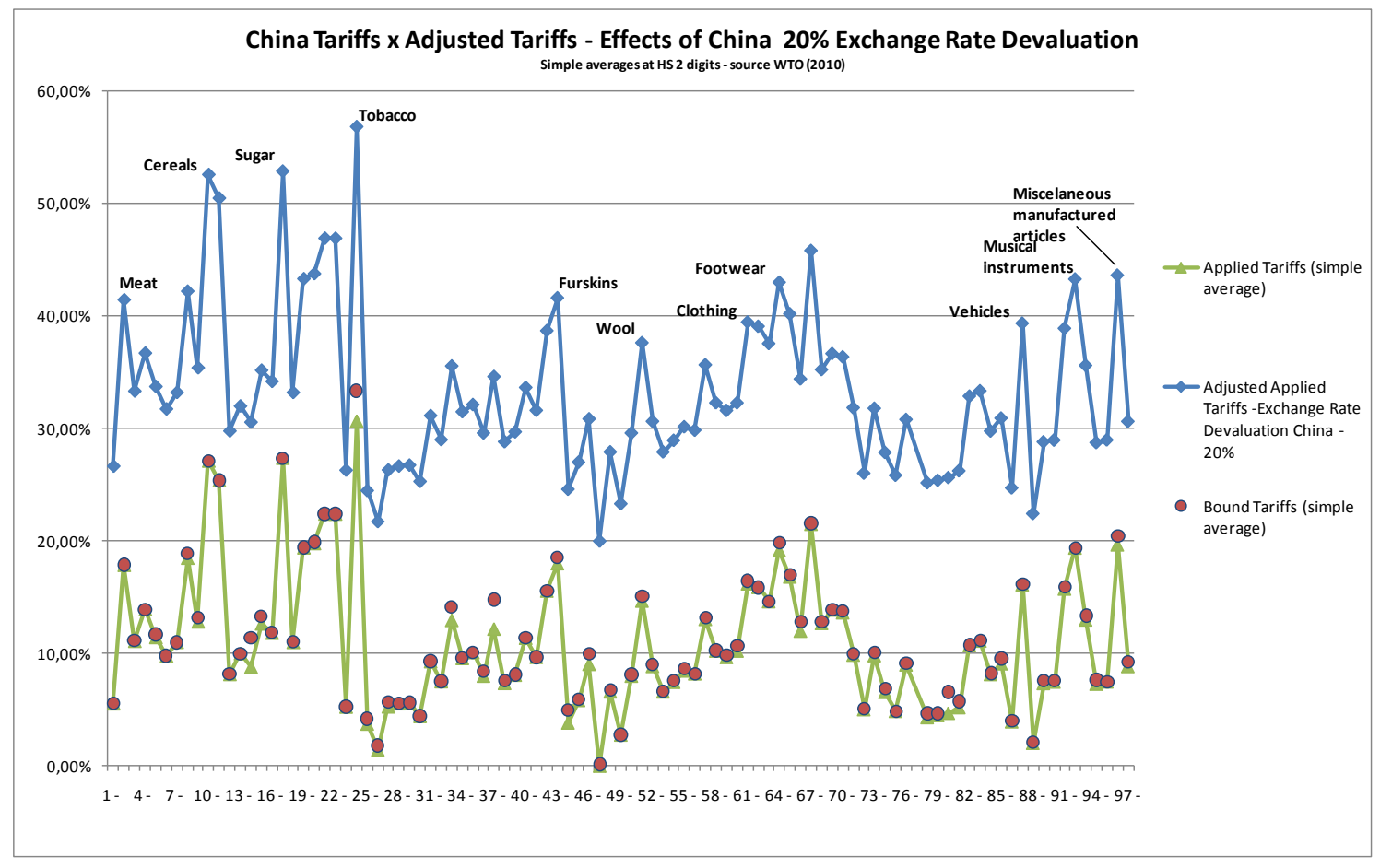

ii) Considering a devaluation of $10 \%$ in the US exchange rate:

- China's average bound and applied tariff, currently varying from $0 \%$ to $33 \%$, will vary from $-10 \%$ to $+18 \%$.

iv) When the effects of both deviations are calculated simultaneously, the effects in China will be the following:

- Considering the effect of China's $20 \%$ exchange rate devaluation and US's $10 \%$ exchange rate devaluation, those tariffs currently varying from $0 \%$ to $33 \%$, will vary from $+10 \%$ to $+44 \%$. 


\section{Graphic 10:}

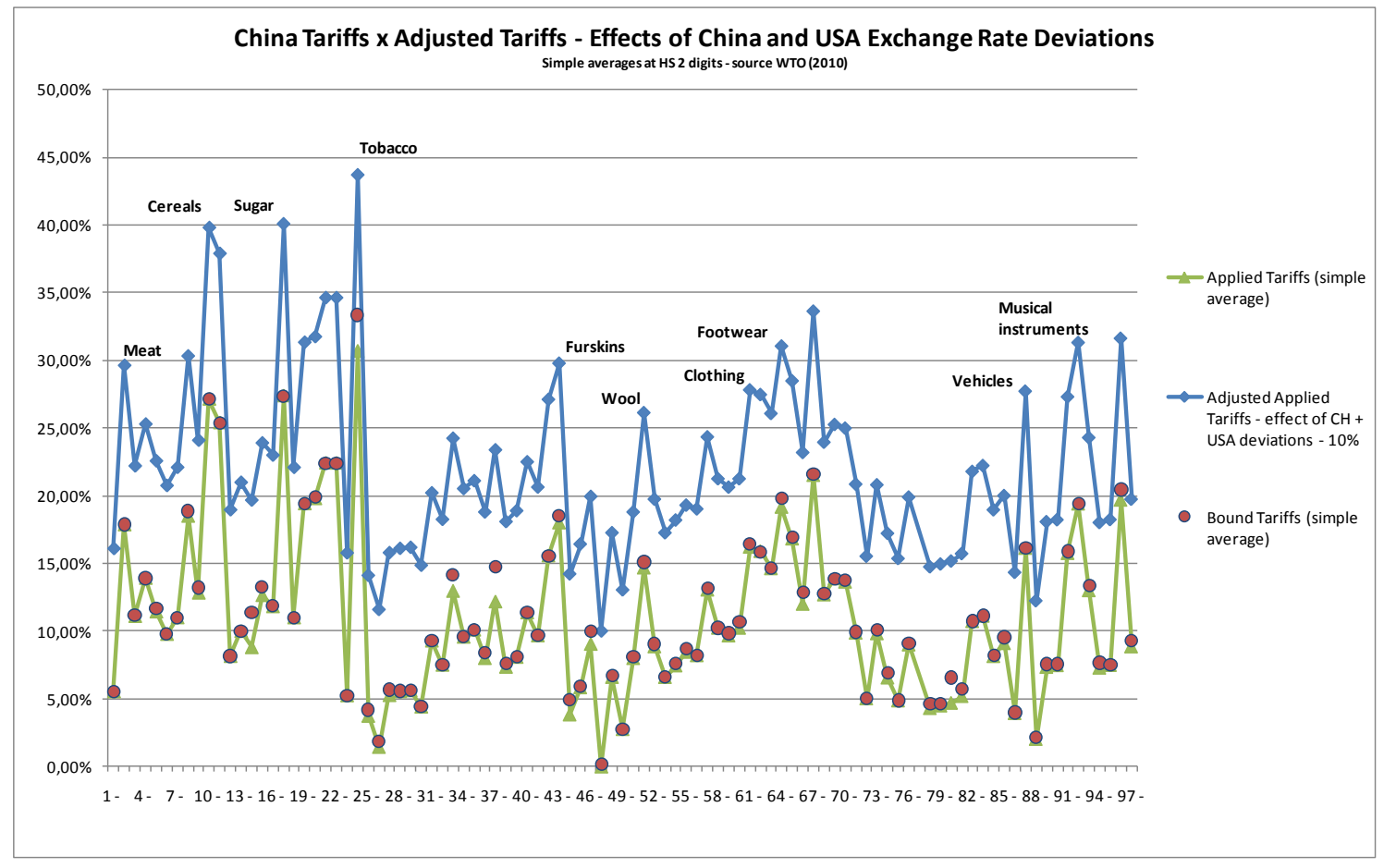

In summary, as shown in the US case, the devaluation of the exchange rate not only represents a stimulus to devaluated currency countries' exports, but also creates an extra tariff to other countries' imports. As the values are also above the WTO's bound tariffs, one could once more raise the question whether those countries are violating the WTO's rules, bearing in mind that GATT Article II establishes that the contracting parties shall not apply excess tariffs to the bound tariffs.

Some authors argue that China's devaluation, which represents a subsidy to its exports, is compensated by Chinese imports, which are penalized with higher tariffs. Nevertheless, as a significant share of Chinese imports comes from countries which China has preferential trade agreements (ASEAN) or are imported to processing zones where they are re-exported, those extra tariffs are partially nullified, changing the misalignment into another stimulus to Chinese exports.

\section{Some conclusions}

In conclusion, the coexistence of two exchange rate misalignments, one of overvaluation and other of devaluation when applied for extended periods, represents a serious distortion for many international trade policies, especially for tariff policy instruments, which are essential for efficient rules and practices.

The possible simulations on exchange misalignments on countries' tariffs are limitless since each country will have a different set of adjusted tariffs for each bilateral trade relationship, considering both countries deviations. The problem is, thus, systemic, affecting potentially every contracting party, with different degrees of distortion. These distortions will be greater where the difference between each country`s exchange rate deviation is wider. 


\section{IV - Exchange rate misalignments and GATT Article II}

The basic rules for market access in the context of the GATT/WTO are in GATT Article II. Article II.1(a) establishes that " each contracting party shall accord to the commerce of the other contacting parties treatment no less favorable than that provided for in the appropriate Part of the appropriate Schedule annexed to this Agreement". Article II.1 (b) prevents members from imposing other duties and charges or ordinary customs duties in excess to bound tariffs in their Schedules. In other words, countries have to keep their applied tariffs in an equal or lower level than their bound tariffs. It should be noted that paragraph 1(b) is more specific than paragraph 1(a) and its violation automatically means a violation of paragraph 1(a).

By considering exchange rate misalignments as a kind of tariff, through a tariffication exercise, one can obtain "adjusted tariffs" in order to verify whether misalignments are increasing tariffs, against GATT rules. With the simulations presented in this paper, it is possible to raise the issue of whether or not China and the US are violating the two paragraphs of Article II. By devaluating their currencies, China and the US grant a less favorable treatment to imported products than the one determined on their Schedules, since, with the combination of tariffs and exchange rate misalignments, the barriers imposed to products imported from other contracting parties surpass the threshold negotiated at the GATT/WTO. This could mean a violation of GATT Article II.1(a). Furthermore, if China and the US' tariffication of exchange rate misalignments are considered tariffs in the meaning of Article II, violation of Article II.1 (b) could also be found, as the exchange rate misalignment tariff would be charged in excess in relation to the bound tariff ${ }^{3}$.

Nevertheless, it is important to emphasize that not all misalignments are violating Article II. Only the ones affecting the level of market access negotiated by members can be raised at the WTO. This discussion is not new, as it had already occurred during GATT negotiations. As a result of this discussion, the GATT established, on Article II:6, a threshold of $20 \%$ as a minimum rate devaluation to allow the renegotiation of specific bound tariffs. This negotiation has occurred 9 times during GATT era, between 1950 and 1975, allowing the raise of bound specific tariffs of Benelux, Finland (3 times), Israel, Uruguay (twice), Greece and Turkey.

With the end of the dollar/gold exchange standard, the GATT contracting parties created a Working Group whose objective was to adapt the existing mechanism in Article II:6 to the new reality of floating exchange rates. From 1978 to 1980, the Working Group met and issued, in January $29^{\text {th }} 1980$, the "Guidelines for Decisions under Article II:6(a) of the General Agreement (L/4938, 27S/28-29). This document reaffirmed the importance of maintaining the mechanism in order to neutralize the effect of exchange rate devaluation on specific tariffs of contracting parties and kept the threshold of $20 \%$ of exchange rate misalignment as a base for the renegotiation.

\footnotetext{
${ }^{3}$ A deeper analysis on possible violations by exchange rate devaluations can be found in Hudson, G.; Bento de Faria, P. and Peyerl, T., The Legality Of Exchange Rate Undervaluation Under WTO Law, The Graduate Institute of Geneva, Trade and Investment Law Clinic coordinated by Prof. Joost Pauwelyn, June 2011, elaborated upon request by the CGTI.
} 
It should be noted that this threshold was considered reasonable based on the level of the tariff rates at that time. At the present, new exchange rate misalignment threshold could be negotiated in order to adjust tariffs to the current systems of floating or administrated exchange rates.

\section{V - Exchange rate misalignments and GATT Article I - MFN}

Exchange rate misalignments have deep consequences for the multilateral trade system. When countries present persistent exchange rate misalignments, they are affecting one of the most important principles of the GATT, the Most-Favored Nation (MFN), established in Article I of the GATT. It reads as follows:

"1. With respect to customs duties and charges of any kind imposed on or in connection with importation or exportation or imposed on the international transfer of payments for imports or exports, and with respect to the method of levying such duties and charges, and with respect to all rules and formalities in connection with importation and exportation, and with respect to all matters referred to in paragraphs 2 and 4 of Article III,* any advantage, favour, privilege or immunity granted by any contracting party to any product originating in or destined for any other country shall be accorded immediately and unconditionally to the like product originating in or destined for the territories of all other contracting parties."

Under the MFN principle, each contracting party is broadly obliged to accord the same tariff treatment to every other contracting party. Furthermore, any kind of advantage or privilege one contracting party should have in relation to imports and exports with another contracting party should be "immediately and unconditionally" extended to all other contracting parties. This principle aims at bringing two main benefits to the system:

Firstly, it guarantees that no particular country will have a commercial advantage in its trade with another contracting party, which otherwise could raise tensions and divert trade. This is a broad guarantee, encompassing any kind of benefit a particular country could have in its trade with another country part to the system. The aim here is to avoid arbitrary allocation of trade flows between contracting parties, which could harm the benefits brought by international trade competitiveness.

Secondly, it protects the stability of the system. Since a producer knows he will face the same tariff barrier to export to a particular country no matter where he exports from, he will be able to decide where to produce without taking applied tariffs into consideration. It also brings predictability and provides a better environment for production to seek whichever country presents better comparative advantages. In this sense, the MFN principle stands as one of the main pillars of the multilateral trade system established after the Second World War in response to the economic turmoil of the 30s, enhanced by protectionist and arbitrary measures which were applied in that period.

The misalignment (and possible manipulation) of exchange rates, however, brings another variable to the equation, with no direct connection to fair competitive features. The particular exchange rate of a country, and its variation from a level considered of medium term equilibrium, could represent an "advantage or privilege" in bilateral commercial relations between a set of countries when compared with other exchange 
rates portraying different levels of variation from their equilibrium. This is due to the effect exchange rate misalignments have on tariffs applied by each country.

After the fall of the fixed exchange rate system under the auspices of the IMF during the 70 s and its substitution with a floating exchange rate system, the CONTRACTING PARTIES to the GATT have manifested their concern with its consequence to the multilateral trade system. In particular, the impact on market access actually faced by exporters was highlighted in a floating exchange rate system:

"1. The CONTRACTING PARTIES, while not questioning the floating exchange rate system and the contributions it has made, acknowledge that in certain circumstances exchange market instability contributes to market uncertainty for traders and investors and may lead to pressures to increased protection; these problems cannot be remedied by protective trade action" (Exchange Rate Fluctuations and their Effect on Trade Fortieth Session of the CONTRACTING PARTIES, Action taken on 30 November $1984-\mathrm{L} / 5761)$

When exchange rate misalignments are "tariffied" and applied to a country's tariffs, a better picture can be offered of the uncertainties brought to the system by the exchange market instability. It can also provide the level of tariff barriers actually faced by exporters from a particular country when destined to another country.

\section{The effect of misalignment on applied tariffs}

To better understand the effects of exchange variation on MNF principle, the tariff profile of some countries can be considered and simulations of the impact on their applied tariffs can be made through the tarification exercise of exchange rate misalignments. The results are presented in the following graphics.

In summary, for each country considered, the combined effects of exchange rate misalignment on applied tariffs (simple average -2 digits of the HS), will present different tariff profiles for the same country. In other words, considering the new "adjusted tariffs", each exporter will face a different market access situation depending from which country he exports his products.

The first market analyzed is the US and exports from China and Brazil are depicted. The second one is China's market and exports from the US and Brazil are depicted. By the MFN principle, each of these exports should be facing the same tariff treatment to reach the US market, which is not the case. The same happens when Chinese market is considered.

\section{- The US market}

The first graphic shows the applied and bound tariffs of the US before any exchange rate effect is considered.

For Chinese exporters, if the US has its currency devaluated by $10 \%$, it has the effect of raising US tariff rates. If China's exchange rate is devaluated in $20 \%$, it has the effect of lowering the tariffs applied by the US. When both misalignments are considered, the US 
devaluation offsets, partially, the Chinese misalignment effect. The upcoming result is around a $10 \%$ lowering effect on US tariffs when faced by Chinese exporters.

For Brazilian exporters, if the US has its currency devaluated by $10 \%$, it has the same effect of raising US tariffs rates. If Brazil's exchange rate is overvalued by $30 \%$, it has the effect of raising the tariffs applied by the US. When both misalignments are considered, as they bear the same effect, the result is an effect of around $40 \%$ raise on US tariffs when faced by Brazilian exporters.

Since each export country is facing a different tariff profile, one can wonder about the effectiveness of the MFN principle established by GATT Article I, "that any advantage, favor, privilege or immunity granted by any contracting party to any product originating in or destined for any other country shall be accorded immediately and unconditionally to the like product originating in or destined for the territories of all other contracting parties."

\section{Graphic 11:}

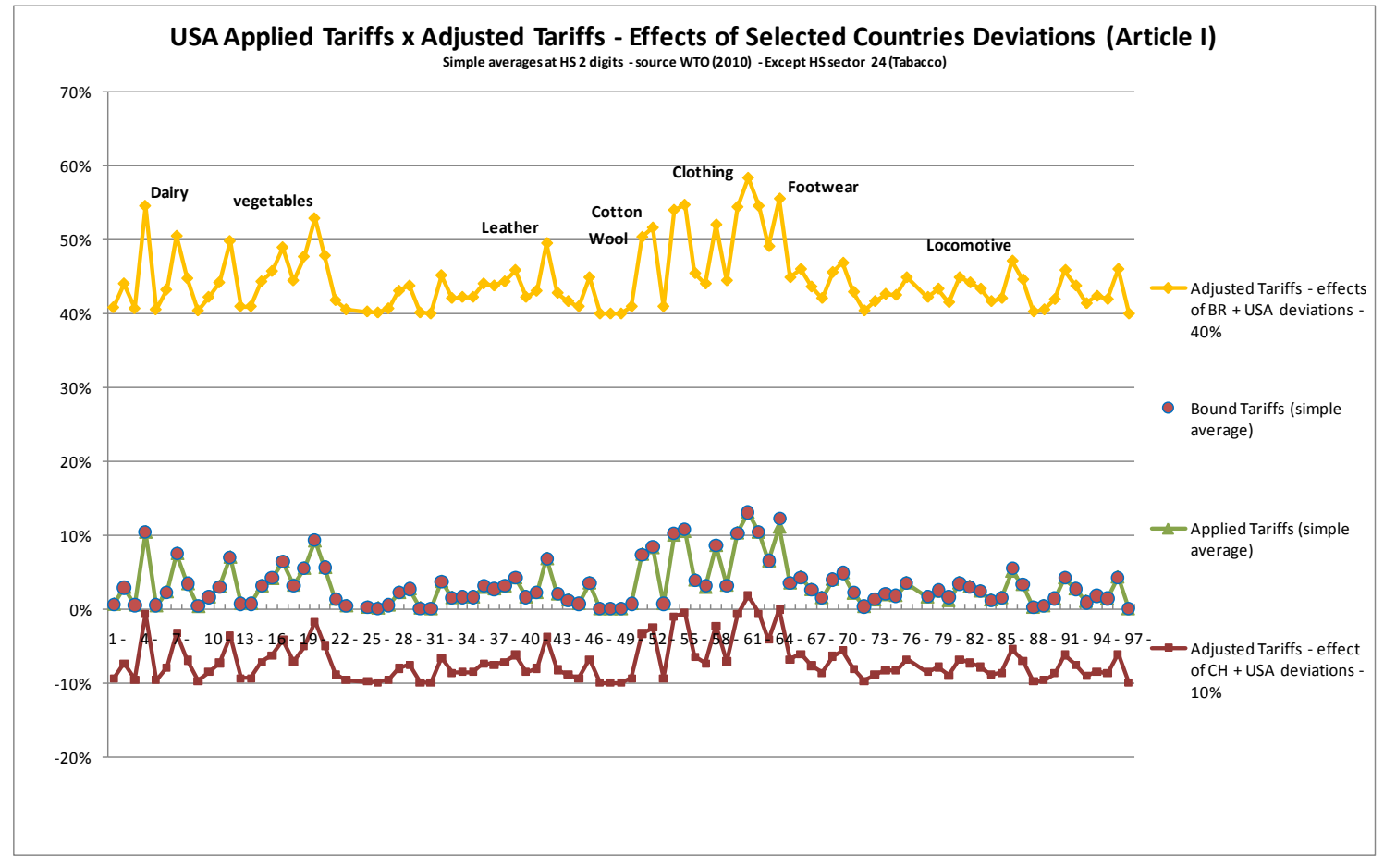

\section{- The Chinese Market}

The second graphic shows the applied and bound tariffs of China before any exchange rate effect is considered.

For US exporters, if China has its currency devaluated by $20 \%$, it has the effect of raising its own tariff rates. If the US's exchange rate is devaluated by $10 \%$, it has the effect of lowering the tariffs applied by China. When both misalignments are considered, the US devaluation offsets, partially, the Chinese misalignment effect. The upcoming result is around a 10\% raising effect on China's tariffs faced by US exporters. 
For Brazilian exporters, if China has its currency devaluated by $20 \%$, it has also the effect of raising its own tariff rates. If the Brazil's exchange rate is overvalued by $30 \%$, it has the effect of raising tariffs applied by China. When both misalignments are considered, as they bear the same effect, the result is around a 50\% raising effect on China's tariffs faced by Brazilian exporters.

Once again, each export country is facing a different tariff profile, and again one can wonder about the effectiveness of the MFN principle established by GATT Article I.

\section{Graphic 12:}

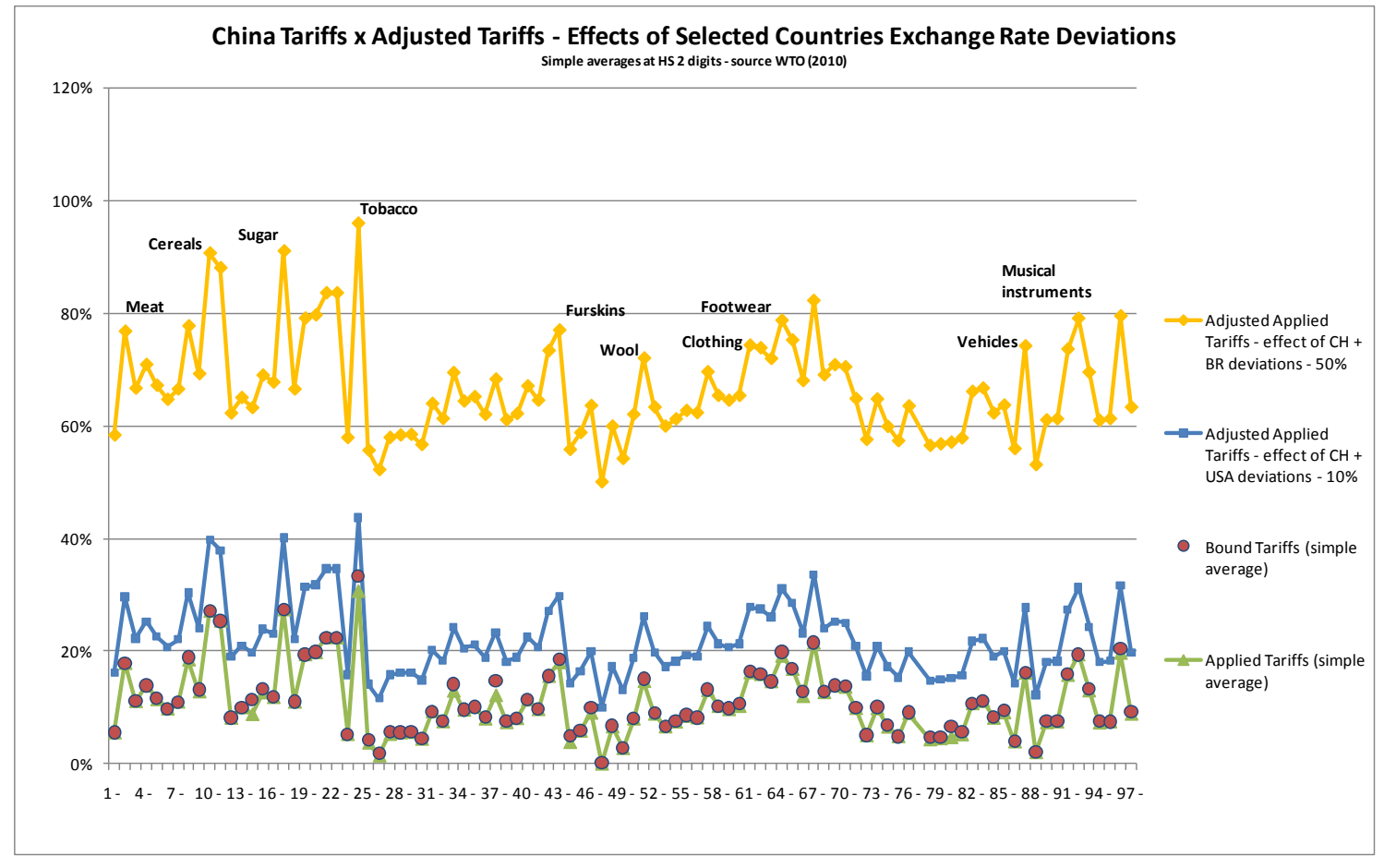

The same simulation can be done for any other chosen market. Each market will present a different tariff profile for each commercial partner. The adjusted tariff rates will vary widely depending on the exchange rate misalignments considered.

\section{VI - Conclusions}

Tariffs are still an important international trade policy instrument for many WTO members. They are the single instrument allowed for market protection in accordance with WTO rules. For decades, negotiations on tariffs were the main objective of the GATT rounds.

The exchange rate issue and its impacts on international trade policy instruments have been ignored, by consensus of the parties, not only by the GATT but by the WTO as well. Although being present in some articles of the GATT and in some agreements of the WTO, the effects of exchange rate misalignments on trade regulation were never taken into consideration, institutionally, by its members. The main GATT article to foresee the effect of exchange rates, Article XV.4 has never been tested neither by the GATT nor by the WTO dispute settlement bodies. 
However, the misalignments of exchange rates have significant impacts on the application of trade principles and instruments: it can affect market access concessions. They can affect the balance of tariff negotiation achieved through several multilateral trade rounds. Their effects on tariffs can represent commercial advantage gains for countries with devaluated currencies.

A more accurate analysis about the effects of exchange rates on tariffs demonstrates that this issue can no longer be ignored by the WTO. Tariffs, that were, for decades, the basic instrument in trade negotiations, end up being nullified by the effects of exchange rate misalignments. More than that, exchange rate misalignments affect directly the level of concessions offered in negotiations and the extent of market access bound at the WTO.

GATT Article II, the legal rule guaranteeing the level of negotiated market access, has never been raised at the Dispute Settlement Body under exchange rate terms, despite the potentially violating effects of those misalignments.

Furthermore, misalignments can bring unpredictability to the multilateral trade system and undermine one of the main pillars of the WTO: the MFN principle. The simulations above demonstrated that due to exchange rate misalignment, exporters from different countries will each face different access conditions in any particular importing market, contrary to what the MFN principle seeks.

With the progressive tariff rate reduction throughout the negotiation rounds, and due to the high level of exchange rate misalignments maintained by several important countries, the exchange rate misalignments end up having a greater relevance than tariffs themselves. Moreover, for devaluated exchange rate countries, this misalignment not only converts itself into an export subsidy, but also into an import surcharge, and, thus, into a much more effective trade barrier than applied tariffs.

Several questions can be raised when observing that Doha Round negotiations are blocked because members such as the US are demanding more concessions from emerging countries. One can ask about the real level of market access offered by this country, given that its exchange rate policy is clearly nullifying all its offers in the negotiations. The level of market access granted by members who practice long term exchange rate devaluation can be put in doubt. How large were in reality the tariff cuts offered in the last few years of negotiations?

Historically, until the 1970s, the GATT's contracting parties accepted the renegotiation of specific tariffs of some countries which faced exchange rate misalignments. During these renegotiations, the threshold provided by Article II was used so that exchange rate misalignments would allow the renegotiation of specific bound tariffs. The question is: why not reconsider the exchange rate issue and negotiate a new threshold?

Regarding market access, only by the introduction of the concept of adjusted tariffs for the exchange rate effect, would the WTO members be able to analyze the real levels of market access negotiated and guarantee the level of the market access protection committed in the negotiation. 


\section{SECTION II}

\section{Exchange Rate Misalignment: definitions, measurement methodology and estimations}

The main purpose of this section is to present the methodology for calculating exchange rate misalignments, its underlying principles on fundamentals and its econometric methods. Finally, to estimate Brazil's and the US's exchange rate misalignments. The calculations for the other members of the G-20 countries are in progress, within the activities of the CEMAP at São Paulo School of Economics - FGV.

There is an important debate in the literature on the methodology and on which variables to use in the determination of the long run real exchange rate. One can point out the Purchasing Power Parity (PPP) theory, a simple and traditional methodology. This theory determines that the exchange rate of a country against its trading partners, adjusted by the difference between price levels, should be stable in the long term, due to the international arbitration in goods markets. A popular version of this approach is the Big Mac Index which compares prices of a particular good in various cities around the world.

However, validity test of any PPP application remains open. Results would not come but in a long term perspective, considering that any deviation from equilibrium would be hard and long enough to be eliminated.

\section{The determinants of real exchange rate}

There is a theoretical discussion on what are the variables behind the determination of long-run fundamentals. An older literature dates back to the work of Edwards (1987) and Dornbusch (1976). The first analyzes the so-called Economy of Misalignment, its causes and consequences. The second is a classic model of flexible exchange rates where monetary policy shocks cause variations beyond the long run fundamentals (PPP - Purchasing Power Parity).

The works of Bilson (1979) and Mussa (1976) are also classics in the literature and include the so-called Monetary Approach to exchange rate. Under this approach, the exchange rate would be determined primarily due to the relative evolution of output and money supply across countries, assuming the continuous validity of purchasing power parity and uncovered interest parity (UIP), as well as a stable money demand in the countries. The work of Meese and Rogoff (1983) cast doubt on the explanatory power of this theory by showing that the predictions obtained from this approach are not superior to a "naive model" such as a pure random walk for the exchange rate. Stein (1995) proposes the approach of the natural rate of exchange (NATREX). According to the author, the equilibrium exchange rate is the one that equals the level of savings to the level of investment generated by the economic fundamentals.

A more recent discussion in the misalignment literature is presented by Williamson (1994). The concept of equilibrium exchange rate is the one that allows the country to maintain a determined deficit or surplus (seen as sustainable) in the current account. This is the Fundamental Real Exchange Rate Approach - FRER. Another more recent reference to this approach is Cline (2008). One criticism to this approach has to do with the fact that there is a high degree of arbitrariness due to the subjectivity in choosing the 
target level of current accounts. Moreover, this kind of approach focuses exclusively on flows and not on stocks.

Faruqee (1995) tries to incorporate issues related to the evolution of stocks and builds a model which allows an interaction between flows and stocks. In this way, he shows that there must be a stable relationship between real exchange rate and net external position of liabilities between residents and nonresidents. This is the Behavioral Real Exchange Rate Approach - BRER. The model is extended by Alberola, Cervero et al. (1999). Kubota (2009) uses a model where the representative agent maximizes the intertemporal consumption and accumulates capital. Under this model, the real exchange rate is a function of terms of trade, net external position, relative productivity of tradable and non-tradable sectors. This is the approach used by CEMAP in its estimation of misalignments.

This approach seeks to reduce the existing degree of subjectivity in the estimation of exchange rate misalignment by connecting the real exchange rate to a set of fundamentals obtained from some theoretical model and decompose the actual real exchange rate series and the fundamentals in transitory and permanent components, using time series econometric techniques.

\section{How to choose the fundamentals?}

The approach of the literature of exchange rate misalignment recognizes both empirical and theoretical limitations of the Purchasing Power Parity (PPP) methodology and uses an approach based on economic fundamentals. These fundamentals are derived from an economic model which takes into account the dynamics of current account and capital account in the calculations of the equilibrium exchange rate. The econometric model contains the following variables: net foreign investment position (NFA), terms of trade (ToT), and a productivity indicator amongst the producing sectors of tradable goods and non-tradable goods (BS). BS is a relative indicator measure of tradable and non-tradable productivity comparing the country to its trading patterns in order to correct the classical effect of the Balassa-Samuelson on real exchange rate.

With these variables, the equilibrium exchange rate of long-term is estimated. Deviations from this rate with the observed exchange rate are the exchange rate misalignments.

(1) RER $_{t}=$ fundamentals $_{t}+$ misalignment $_{t}$

(2) fundamentals f $_{t}=f\left(N F A_{t}^{\text {equilibrim }}, T T_{t}^{\text {equilibrim }}, B S_{t}^{\text {equilibrim }}\right)$

The real exchange rate of long-run equilibrium can be estimated from a time series econometric model that aims to estimate the structure given by (1) and (2).

\section{How to estimate the misalignment?}

The estimation is made by the decomposition of the series in transitory and permanent components, after an analysis of stationarity and co-integration (Engle and Granger (1987), Johansen (1995) and Gonzalo and Granger (1995)). The transitory component is connected to the misalignment and the permanent component is connected to the long run equilibrium. The economic series individually analyzed, in general, do not tend to 
revert to some level of long run position due to non-stationarity. In a technical way, the economic series are integrated, i.e., shocks are accumulating over time. The series are said to be co-integrated if shocks accumulate in a common set of series, in such a way that there is a linear combination between them, with a stationary property. Thus, two co-integrated series can drift away only in the short-run, but tend to revert to its longrun equilibrium. The real exchange rate can move away from certain series called fundamentals, but if they are indeed a long-run determinant of the exchange rate, then the series will revert to its long-run equilibrium.

\section{Results}

CEMAP estimated Brazil's and the US's real equilibrium exchange rate, using cointegration techniques. The econometric model contains the series of fundamentals listed above. The results are as follows:

\section{Estimates for Brazil}

Graphic 13 shows the evolution of the level of misalignment observed in the Brazilian economy from 1980 to 2010. The estimates suggest that the highest positive real exchange misalignment occurred in 1998 with the Brazilian real exchange rate being on average about $25 \%$ above the equilibrium. The highest negative misalignment level occurred in 2003, with the exchange rate being about $23 \%$ below equilibrium. The first stage is associated with the macroeconomic stabilization of the Brazilian economy in which the exchange was not floating. The second period concerns the effects of the crisis of confidence in the transition from Cardoso to Lula. The graphic also suggests that an exchange rate misalignment has a high degree of persistence. Periods of positive misalignments tend to be followed by other periods of positive misalignment and the same goes for negative values.

The line of fundamentals, which denotes the value of long-run equilibrium to which the real exchange rate should converge, shows that in the 1990's there was a trend of worsening of fundamentals that was halted and reversed during the year 2000. In recent years, the line of foundations remains stable while the real exchange rate presents a strong appreciation.

Estimating the real equilibrium exchange rate is a complex task and raises long discussions. The estimates are subject to the customary caution, especially for periods at the end of the sample, in which all the developments of recent events have not been fully expressed in the series, which can distort the estimate in some unknown way. The model estimated here suggests that the Brazilian exchange rate has been far from equilibrium in 2010, and the misalignment was growing at the end of the year. It is estimated that in 2010 the exchange rate was about $29 \%$ above the equilibrium, a value very close to the ceiling of the series calculated from 1980.

With the exception of the first quarter of 2009 , due to the financial crisis, the Brazilian exchange rate remains consistently above the equilibrium since 2005. From this year, also the fundamentals lines apparently reverted. This suggests fundamentals improvements in the early 2000 were exhausted. However, the Brazilian exchange rate continued appreciating against a relevant basket of trade patterns. 
The measure of exchange rate misalignment should not be used as a prediction of the real exchange rate. Misalignment of the Brazilian currency does not necessarily imply that immediate realignments will occur, but only at some point in the future. It is very difficult to state the time when such adjustment will occur and its intensity. The measure must be understood as an indicator of some kind of imbalance at the present time, but not necessarily in the future. Unforeseen improvements in the fundamentals, such as additional gains in terms of trade and the improvement in the external position of investments, for instance, can cause the line of fundamentals to approach the current level of exchange rate.

\section{Graphic 13: Brazil: real exchange rate, fundamentals and exchange rate misalignments}
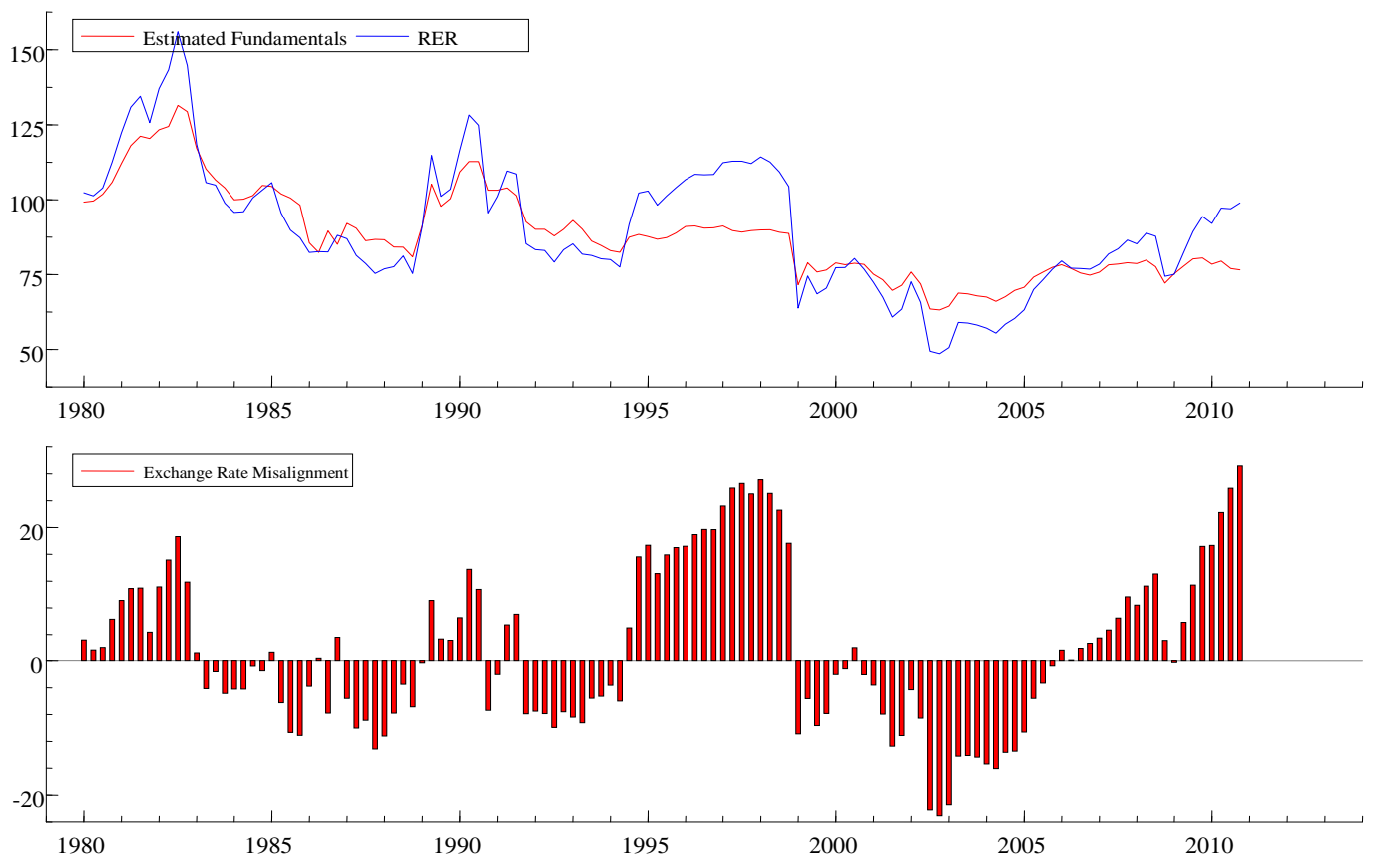

Source: CEMAP.

\section{Estimates for the United States:}

Graphic 14 shows the evolution of the level of misalignment observed in the US economy from 1970 to 2010 . The estimates of exchange rate misalignment suggest two moments of overvaluation of the dollar. The first occurred in the first half of the 1980s. The second stage began in the mid-1990s and lasted until the first half of the years 2000. In both cases the US exchange rates reached a value of about $40 \%$ above the equilibrium. The line of fundamentals, which denotes the value of long-run equilibrium to which the exchange rate should converge, shows a continuing trend of worsening fundamentals of the US economy. Apparently, since 2005, the fundamentals began to revert smoothly.

The model suggests that the US exchange rate has been below its equilibrium over 2010. The values are not as high as the ones observed in other periods, but are between $5 \%$ and $10 \%$ depending on the year under analysis. 
Graphic 14: United States: real exchange rate, fundamentals and exchange rate misalignments
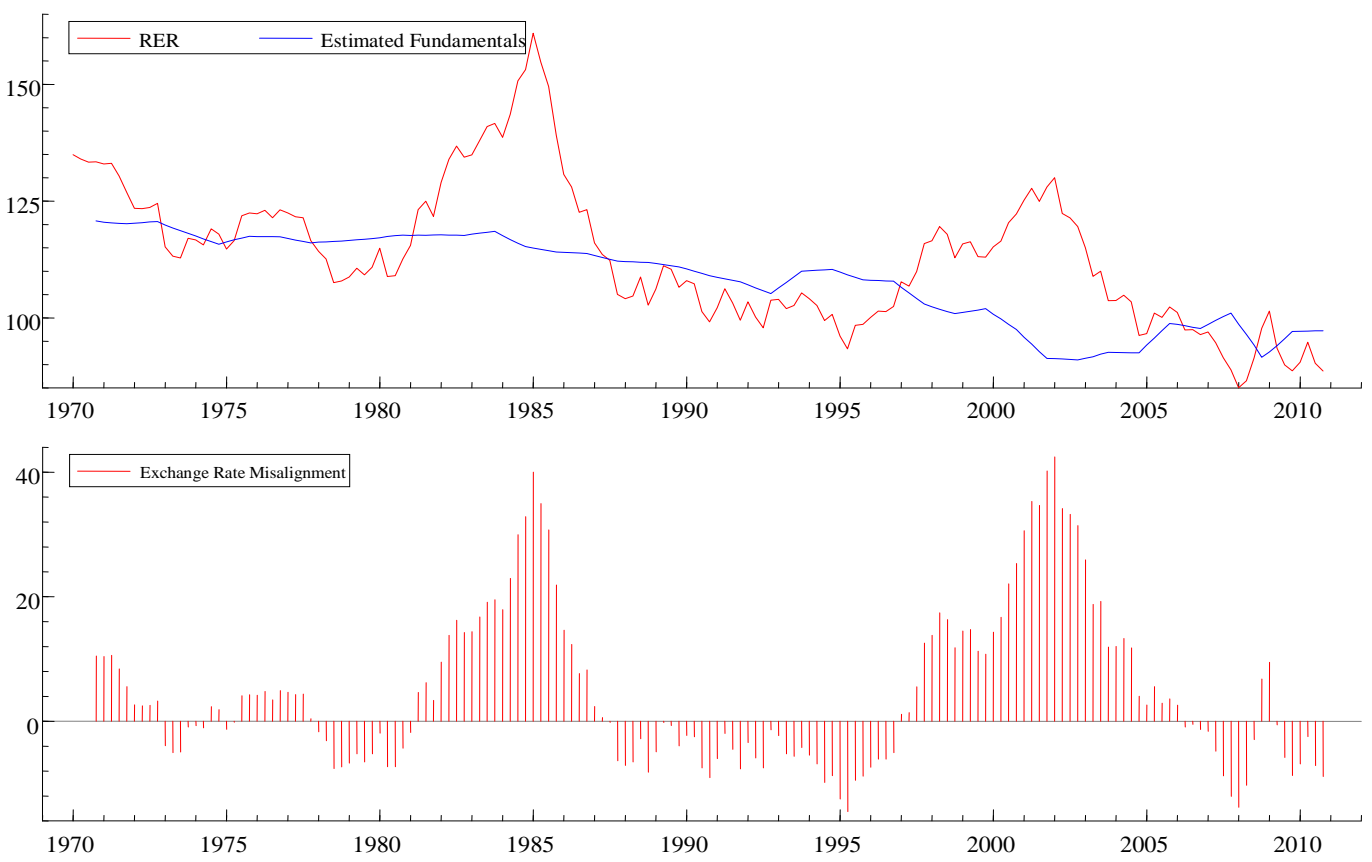

Source: CEMAP.

\section{Estimates for China}

Graphic 15 shows the evolution of the level of misalignment observed in China economy from 1980 to 2010.

CEMAP analysis the determinants of Chinese real exchange rate in this period using cointegration techniques and the data set that contains real exchange rate (RER), net foreign asset position (NFA), the level of international official reserves as percentage of gross domestic product (RGDP) and difference of gross per capita income between China and their main trading patterns (DiffPercapita). The introduction of reserves in the Vector Error Correction Model is not the usual practice in the literature. In this paper, with the inclusion of official reserves, evidence was obtained in favor of cointegration hypothesis among these variables. Whereas the traditional model without official reserves does not give evidence in favor of cointegration. The variables NFA, RGDP and DiffPercapita can be seen as long run determinants of real exchange rate. From the model it is possible to estimate the level of Chinese exchange rate misalignment. 
Graphic 15: China: real exchange rate, fundamentals and exchange rate misalignments
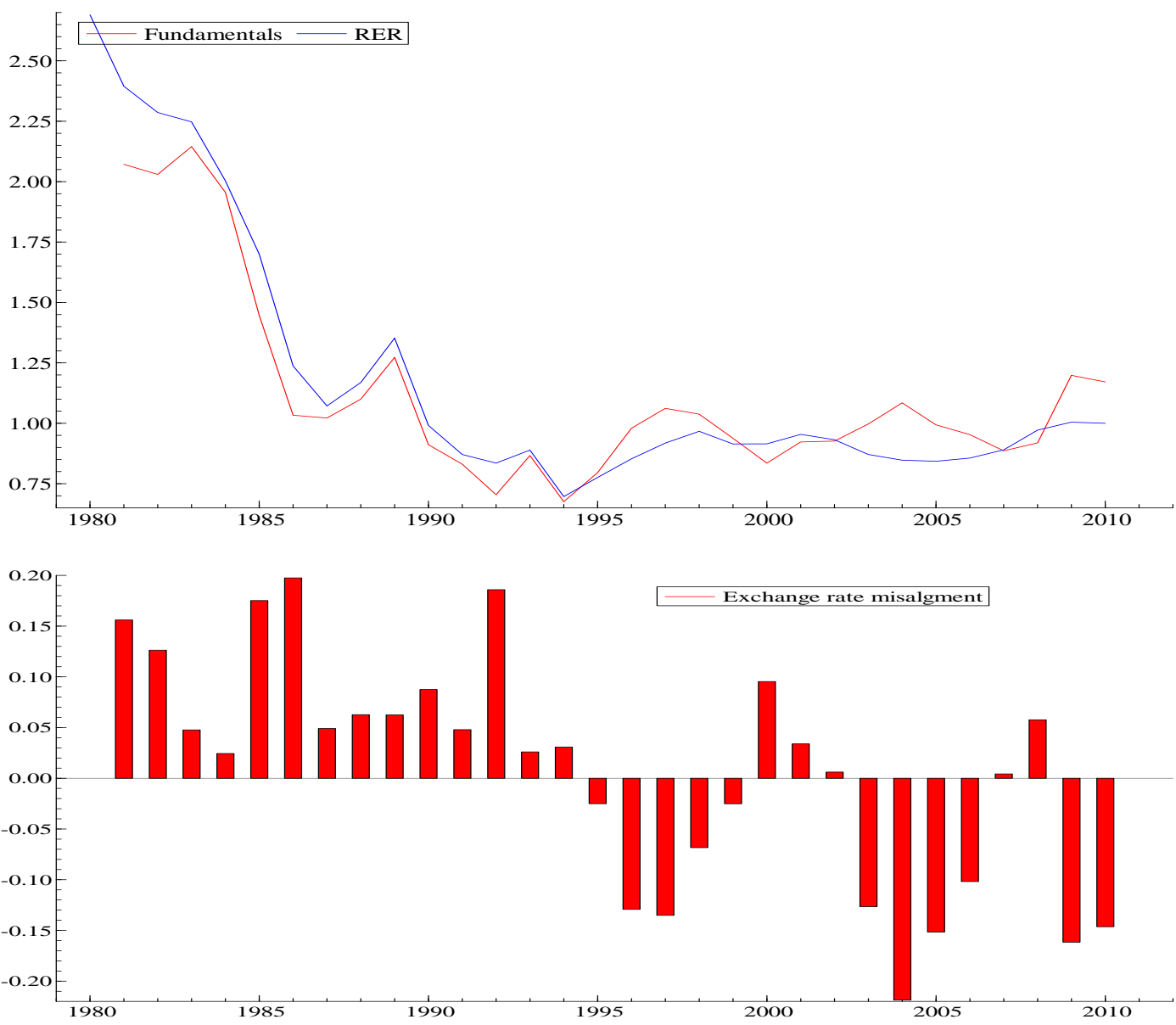

Source: CEMAP.

In summary, CEMAP has estimated exchange rate misalignment following the methodology based on the analysis of long-term fundamentals of the real exchange rate using a Vector Autoregressive Model with Error Connection Term as econometric model. It has used as fundamentals the net foreign investment position, terms of trade and an indicator of difference in productivity in the sectors of tradable and non-tradable goods. There is theoretical justification for such choice, and the relationship between real exchange rate and these variables is empirically validated as shown by Faruqee, $\mathrm{H}$. (1995), Alberola, E., S. Cervero, H. Lopez and A. Ubid (1999) and Kubota, M. (2009).

Based on this model, CEMAP estimated Brazil's exchange rate misalignment in the end of 2010 by about $+29 \%$, which means that the Brazilian currency would have to be depreciated around this value to achieve the estimated equilibrium. The same calculation was made for the US and the result was a misalignment of about $-10 \%$, which means that the US currency should appreciate in this amount to achieve the longrun equilibrium. Once again, the same calculation was made for China and the result was a misalignment of about $-17 \%$, which means that China currency should appreciate in this amount to achieve the long-run equilibrium. These figures should be considered based on the conditions prevailing in the analyzed period. 


\section{SECTION III}

Estimation of the impact of exchange rate misalignments on the level of tariff protection (a tarifficaton exercise)

The first step to estimate the impact of exchange rate misalignments on the level of tariff protection is to express local import prices as a function of international prices, equilibrium exchange rates and tariff barriers.

In a given bilateral trade relationship, the price of the good imported by the domestic economy can be written as in equation (1):

$$
\mathrm{P}_{\mathrm{imp}}^{\mathrm{dom}}=\mathrm{P}_{\mathrm{exp}}^{*} \cdot \Theta_{\mathrm{dom}} \cdot(1+\mathrm{t})
$$

Where:

$\mathrm{P}_{\mathrm{imp}}^{\mathrm{dom}}$ : domestic price of the good imported, expressed in local domestic currency;

$\mathrm{P}_{\mathrm{exp}}^{*}$ : international price of the good exported by the foreign economy;

$\Theta_{\mathrm{dom}}$ : nominal exchange rate in the domestic economy;

$(1+\mathrm{t})$ : Tariff barrier (tariff effect);

The international price of the good exported by the foreign economy $\left(\mathrm{P}_{\exp }^{*}\right)$ can be written as in equation (2):

$$
\mathrm{P}_{\mathrm{exp}}^{*}=\mathrm{P}_{\mathrm{dom}}^{*} \cdot \frac{1}{\Theta^{*}}
$$

Where,

$\mathrm{P}_{\mathrm{dom}}^{*}$ : foreign price of the good exported by the foreign economy, expressed in local foreign currency;

$\Theta^{*}$ : nominal exchange rate in the foreign economy;

Therefore, equation (1) can be rewritten as in (3):

$$
\mathrm{P}_{\mathrm{imp}}^{\mathrm{dom}}=\mathrm{P}_{\mathrm{dom}}^{*} \cdot \frac{1}{\Theta^{*}} \Theta_{\mathrm{dom}} \cdot(1+\mathrm{t})
$$

The impact of possible exchange rate misalignments on import domestic prices can be estimated by first taking logs in both sides of equation (3) and then linearizing it. This procedure allows equation (3) to be expressed in percentage form, according to equation (4) below:

$$
\frac{d\left(P_{\text {imp }}^{\text {dom }}\right)}{P_{\text {imp }}^{\text {dom }}}=\frac{d\left(P_{\text {dom }}^{*}\right)}{P_{\text {dom }}^{*}}-\frac{d\left(\Theta^{*}\right)}{\Theta^{*}}+\frac{d\left(\Theta_{\text {dom }}\right)}{\Theta_{\text {dom }}}+\frac{d(1+t)}{1+t}
$$

Assuming the price of the foreign good $\mathrm{P}_{\text {dom }}^{*}$ (expressed in local foreign currency) to be less sensitive to exchange rate misalignments (e.g. low import content or existence of government import subsidies), equation (4) can be rewritten as: 


$$
\frac{d\left(P_{\text {imp }}^{\text {dom }}\right)}{P_{\text {imp }}^{\text {dom }}}=-\frac{d\left(\Theta^{*}\right)}{\Theta^{*}}+\frac{d\left(\Theta_{\text {dom }}\right)}{\Theta_{\text {dom }}}
$$

That is, we can write the fluctuations in the local price of the goods imported by the domestic economy only as a function of exchange rate misalignments, both in the domestic economy as well as in the foreign economy. As noted in equation (5), foreign currency devaluations contribute to the increased competitiveness of the good imported by the domestic economy, making it cheaper (because $\left(d\left(\Theta^{*}\right) / \Theta^{*}\right) \geq 0$ ). The same reasoning applies to domestic currency valuations (because $\left.\left(\mathrm{d}\left(\Theta_{\mathrm{dom}}\right) / \Theta_{\mathrm{dom}}\right) \leq 0\right)$.

For the calculation of an import tariff adjusted to exchange rate misalignments (percentage) as described in (5), it is possible to rewrite the equation (3) in the form of deviations from the equilibrium exchange rates. For instance, in the case where the exporting foreign economy manipulates its exchange rate so as to make its exports more competitive (devaluation) and the importing domestic economy operates with an overvalued exchange rate, equation (3) can be rewritten with the following adjustments in the rates of equilibrium:

$$
\left(1+\left(-\frac{\mathrm{d}\left(\Theta^{*}\right)}{\Theta^{*}}+\frac{\mathrm{d}\left(\Theta_{\mathrm{dom}}\right)}{\Theta_{\mathrm{dom}}}\right)\right) \cdot P_{\mathrm{imp}}^{\mathrm{dom}}=\mathrm{P}_{\mathrm{dom}}^{*} \cdot \frac{1}{\Theta^{*}} \cdot \Theta_{\mathrm{dom}} \cdot(1+\mathrm{t}) \cdot\left(1+\left(-\frac{\mathrm{d}\left(\Theta^{*}\right)}{\Theta^{*}}+\frac{\mathrm{d}\left(\Theta_{\mathrm{dom}}\right)}{\Theta_{\mathrm{dom}}}\right)\right)
$$

So, it is possible to define an import tariff adjusted for currency fluctuations, as follows:

$$
(1+\mathrm{t}) \cdot\left(1+\left(-\frac{\mathrm{d}\left(\Theta^{*}\right)}{\Theta^{*}}+\frac{\mathrm{d}\left(\Theta_{\mathrm{dom}}\right)}{\Theta_{\mathrm{dom}}}\right)\right)=\left(1+\mathrm{t}^{\text {ajust }}\right)
$$

Therefore, in order to take into account possible exchange rate misalignments in relation to their equilibrium values, the so called adjusted tariff can be calculated as in (7):

$$
t^{\text {adjust }}=\left(-\frac{d\left(\Theta^{*}\right)}{\Theta^{*}}+\frac{d\left(\Theta_{d o m}\right)}{\Theta_{d o m}}\right)+t .\left(1+\left(-\frac{d\left(\Theta^{*}\right)}{\Theta^{*}}+\frac{d\left(\Theta_{d o m}\right)}{\Theta_{d o m}}\right)\right)
$$

It is worthy of note that equation (7) required some important simplifying assumptions along its estimation path. Firstly, foreign prices (expressed in foreign local currency) were considered to be constant even under foreign exchange rate misalignments. Secondly, the empirically estimated exchange rate misalignments values used in this study were multilateral in nature. That, in principle, could make a difference in value, if only bilateral misalignments were considered. In this sense, the exercise here should be understood as a short-run partial approach to the problem. 


\section{FINAL CONCLUSIONS}

Considering the current diversity of exchange rate policies and the extent of exchange rate misalignments, a question can be raised: could currency wars lead to trade wars?

The first step in seeking for an answer is to study the effects of exchange rate misalignments on the international trade policy of each country and the impact on their trade instruments. If the exchange rate misalignments do affect the objectives of these policies and neutralize the efficiency of their instruments, the answer is clear: yes, currency wars can lead to trade wars.

Examples of trade wars are as old as history itself, as well demonstrated by Findlay and O'Rourke in Power and Plenty (2007). What is new, however, is that, for the last sixty years, countries managed to avoid wars by creating an international forum - the GATT, latter WTO - to negotiate rules to avoid trade conflicts. The main objective of the GATT/WTO is to liberalize international trade and establish a binding regulatory framework for all its members, where their trade activities could be contested at the "juridical-diplomatic tribunal" of the organization.

The seed of the problem was sown, however, with the functional distinction between the GATT and the IMF. The first was created to be responsible for trade and the latter for exchange rates and balance of payments problems, at a time when the whole system of trade regulation worked under the dollar/gold standard regime. However, even after the adoption of floating currencies in the 1970s, the currency topic remained under IMF control.

Since the year 2000, the international arena became more complex with the presence of the emerging countries. China, in particular, became a new economic power and the world's biggest exporter of goods. Agreements amongst few for exchange rate realignments, common in the past, have now become impossible. The exchange rate issue has been globalized and nowadays affects directly the international trade policy of all trade partners.

The exchange rate issue is not totally absent from the WTO. Article XV of the GATT contains, since 1948, rules on exchange arrangements, which state that "Contracting parties shall not, by exchange action, frustrate the intent of the provisions of this Agreement, nor, by trade action, the intent of the provisions of the Articles of Agreement of the International Monetary Fund". With the artificial division agreed in the past between GATT and IMF, WTO members have been refusing to discuss the exchange rate issue and its impacts on trade.

Several proposals for the use of trade remedies, such as anti-dumping and countervailing measures, in order to offset the exchange rate effects have been discussed, but the results appear to be legally questionable under present WTO rules. It is true that trade remedies were not negotiated or agreed as mechanisms to inhibit the use of exchange rates as unfair trade.

Considering the extent of last year's exchange rate misalignments, and their effects on trade, the issue has been taken to the G-20. However, in the presence of impasses and 
crises in several multilateral organizations there is no consensus in that forum on how to address the matter, or even how to define the problem.

While WTO members refuse to discuss the exchange rate effects on trade and how to neutralize them, economists from different parts of the world accumulate a considerable academic production, which can indicate the extent of the problem. There are different methods and methodologies to calculate the equilibrium exchange rates and exchange rate misalignments of the main currencies: the purchasing power parity, the equilibrium of the current account, the equilibrium of assets and liabilities flows of a country, or the exchange rate based on the unit of labor costs.

It is true that such studies present a great variety of results. However, for the WTO, the accuracy of the exchange rates' valuations or devaluations is not relevant. The main task facing the WTO is only to find out a threshold, a red border, from where trade policy instruments, negotiated within the GATT and the WTO, become ineffective as the impacts of exchange rates nullify the effects of the rules negotiated in the trading system over the last six decades.

This research paper aimed to explore the impacts of exchange rates on just one of the main international trade policy instruments: tariffs. It would be opportune to analyze their effects also on trade remedies, such as anti-dumping and countervailing measures, created to defend countries from unfair trade, and safeguard measures, which deal with import surges considered to be fair. The idea is not new. It was proposed by Australia to be included in the Draft of the Havana Charter as it is shown on the Report of the Drafting Committee of the Preparatory Committee of the United Nations Conference on Trade and Employment (UN ECOSOC, E/PC/T/34 of March 5 $\left.{ }^{\text {th }}, 1947\right)$. This proposal attempted to include four kinds of dumping: price, freight, currency and social dumping.

The analysis of preferential rules of origin, a core issue for all bilateral and regional trade agreements, which are widely spreading nowadays, would also be providential. It would be relevant to analyze how misalignment would affect the rules based on value added. Another relevant question to be studied would be the effects of misalignments on the already implemented Quota Free - Duty Free Initiative. Is the desired zero barrier being really achieved?

The results presented in this paper on the effects of exchange on tariffs are evident and strong:

- For countries with an appreciated exchange rate: depending on the level of such appreciation, their bound and applied tariffs can be nullified and become negative, implying that the country is granting a stimulus to imports and waiving the tariff protection level negotiated within the WTO.

- For countries with a depreciated exchange rate: depending on the level of such depreciation, their bound and applied tariffs can be increased in greater proportions than the exchange rate. For countries with a small difference between applied and bound tariffs, any depreciation may imply that applied tariffs surpass the limits negotiated within the WTO, violating Article II of the GATT. 
But is not only Article II that is under discussion. If one considers the addition of bilateral misalignments, even Article I will be undermined, since the tariffs between every pair of countries will vary under the effects of their exchange rates, which may result in different levels of protection vis-à-vis different countries, in violation of the Most Favorable Treatment obligation.

In other words, two basic principles of the WTO are under threat: transparency and predictability. With the impacts of exchange rates, tariff structures become less transparent and much less predictable, in the present context of exchange rates' fluctuations or manipulations. The same impacts also affect other trade policy instruments, such as trade remedies and rules of origin. By eroding such basic principles, exchange rate misalignments, if not neutralized, might undermine WTO's main asset: its members' confidence.

Against the reality of exchange rate misalignments it is no longer acceptable to allow the continuation of the present situation. It is time to start negotiating a mechanism to neutralize exchange rate effects on tariffs, which, when effectively applied, would allow the maintenance of the level of market access previously established.

In summary, the WTO can no longer ignore the effects of exchange rates on its system of rules, which was constructed relentlessly over the last decades. Regarding the current status of the Doha Round, one can ask whether the exchange rate issue is not behind the dead-lock of the negotiations.

The greatest advance presented by the WTO has always been to guarantee that the relations between States be oriented by rules and not by power. The strengthening of the WTO's regulatory system is crucial in order to avoid that trade wars do not become international conflicts.

Paraphrasing a historical dialogue of space exploration, which almost ended up in a tragedy, it would be the case of affirming in a clear voice:

GENEVA - WE HAVE A PROBLEM ! 


\section{BIBLIOGRAPHY}

WTO, 1994, Results of the Uruguay Round Negotiations.

WTO, 2011, Data Base on Tariffs.

IMF, 2010, 2011 - Country Report People's Republic of China: Article IV Consultation, Staff Report, July 2010; Country Report People's Republic of China: Article IV Consultation, Staff Report, July 2011.

Bergsten, F., 2010 - Correcting the Chinese exchange rate: an action plan, US - Sino Currency Dispute: new insights from Economics, Policy and Law, edited by Simon Evenett, Vox EU Publication, April 2010.

Cline, W; Williamson, J., 2010 - Notes on Equilibrium Exchange Rates: January 2010;

Cline, W; Williamson, J., 2011 - Estimates of Fundamental Equilibrium Exchange Rates, Peterson Institute, May 2011.

Credit Suisse, 2011 - Valuation of Emerging Markets Currencies, Debt Trading Monthly, January 2011.

Evenett, S., 2010 - US - Sino Currency Dispute: new insights from Economics, Policy and Law, Vox EU Publication, April 2010.

Ferguson, N.: Schularick, M., 2009- The End of Chimerica, Harvard Business School, WP 10-937, October 2009.

Findlay, R.; O’Rourke, K. - Power and Plenty, Princeton University Press, 2007.

Helmut, R.,2009 - On the Renminbi and Economic Convergence, December 2009, VoxEU.

Rodrick, D., 2009 - Making Room for China in the World Economics, December 2009, VoxEU.

Subramani, A., 2010 - New PPP-Based Estimates of Renminbi Undervaluation and Policy Implications, Peter Institute, PB10-8, April 2010.

\section{BIBLIOGRAPHY RELATED TO METHODOLOGIES ON EXCHANGE RATE MISALIGNMENTS}

Alberola, E., S. Cervero, et al. Global Equilibrium exchange rate: Euro, Dolar, 'Ins', 'Outs' and other major currencies in a Panel Cointegration Framework. IMF Working Paper. Washington: IMF. 99-175 1999.

Bilson, J. F. Recent developments in monetary models of exchange rate determination. IMF Staff Paper, v.26, n.2, p.201-223. 1979.

Cline, W. R. Estimating consistent fundamental equilibrium exchange rate. Working paper Series. Washington: Peterson Institute for International Economics: 1-26 p. 2008.

Dornbusch, R. Expectations and Exchange Rate Dynamics. Journal of Political Economy, v.84, n.6, p.1161-1176. 1976.

Edwards, S. Exchange rate misaligment in developing countries. NBER working paper, v.442. 1987.

Engle, R. F. e C. W. J. Granger. Co-integration and Error Correction: Representation, Estimation and Testing. Econometrica, v.55, p.251-276. 1987.

Faruqee, H. Long-run determinants of the real exchange rate: A stock Flow Perspective. IMF Staff Paper, v.42, p.80-107. 1995. 
Gonzalo, J. e C. W. J. Granger. Estimation of Common Long-Memory Components in Cointegrated Systems. Journal of business and Economics Statistics, v.13, n.1. 1995.

Johansen, S. Likelihood-based inference in cointegrated vector autoregressive models. Oxford: Oxford University Press. 1995. x, 267 p. (Advanced texts in econometrics)

Kubota, M. Real Exchange Rate Misalignments: Theoretical modelling and empirical evidence. Discussion Papers in Economics. York: University of York 2009.

Marçal, Emerson, O mistério da taxa de câmbio real chinesa: algumas razões que podem explicar a diversidade dos resultados, to be published by IPEA, 2012

Marçal, Emerson, Levado pelos fundamentos?Estimando o desalinhamento cambial norte-americano a partir de técnicas de cointegração, TD 1674, IPEA, November, 2011

Marçal, Emerson, Estimando o desalinhamento cambial brasileiro a partir de modelos multivariados com cointegração, TD 1666, IPEA, September, 2011

Meese, R. A. e K. Rogoff. Empirical Exchange models of the seventies: Do they fi out of the sample? Journal of International Economics, v.14, p.3-24. 1983.

Mussa, M. The exchange rate, the balance of payments and monetary policy under a regime of controlled floating. Scadinavian Journal Of Economics, v.78, p.228-248. 1976.

Stein, J. The Fundamental Determinants of the Real Exchange Rate of the U.S. Dollar Relative to Other G-7 Currencies. IMF Working Paper v.95-81. 1995.

Williamson, J. Estimating Equilibrium Exchange Rates. Washington D.C.: IIE. 1994 